\title{
The Expression of the Protein p68/70 within the Goldfish Visual System Suggests a Role in Both Regeneration and Neurogenesis
}

\author{
George R. Wilmot, ${ }^{1}$ Pamela A. Raymond, ${ }^{1,2}$ and Bernard W. Agranoff ${ }^{1,3}$ \\ 'Neuroscience Program, ${ }^{2}$ Department of Anatomy and Cell Biology, and ${ }^{3}$ Department of Biochemistry and Mental Health \\ Research Institute, University of Michigan, Ann Arbor, Michigan 48104
}

\begin{abstract}
Previous attempts to characterize the molecular events that support successful regeneration of axotomized goldfish retinal ganglion cells (RGCs) have led to the discovery of an acidic protein doublet in retina that displays an increased incorporation of ${ }^{35} \mathrm{~S}$-methionine following axotomy, and is known to be axonally transported within the optic nerve. This protein is termed $p 68 / 70$, reflecting its relative migration in $10 \%$ SDS-PAGE. In the present study, an affinity-purified polyclonal antibody to p68/70 (anti-p68/70) was developed and used to assess the species, tissue, and cellular distribution of p68/70. The antibody cross-reacted with homogenates of brain and other tissues from goldfish and closely related fish species. While each goldfish tissue tested expressed $p 68 / 70$, the levels varied over a 30 -fold range, with the highest amounts in brain, egg, and ovary. Immunolabeling of goldfish retina revealed prominent staining of RGC somata, dendrites, and axons. During regeneration, the immunoreactivity of the RGC somata and axons increased dramatically. Intense immunolabeling was also observed in the germinal neuroepithelial cells and rod precursors and in all retinal layers near the peripheral margin, in the region of recently differentiated neurons. In the tectum, the germinal zone was also highly labeled. The elevated expression of p68/70 in each of these areas known to mediate neuronal growth within the goldfish visual system suggests that $p 68$ / 70 plays a role in axonal growth, regrowth, and possibly in neural development as well.
\end{abstract}

[Key words: growth-associated proteins, goldfish, regeneration, p68/70, axotomy, retinal ganglion cells, neurogenesis, visual system, rod precursors]

The goldfish visual system provides a uscful model for studying axonal regeneration within the CNS, since functional recovery typically follows optic nerve crush (Attardi and Sperry, 1963). The intrinsic mechanisms that provide the retinal ganglion cells (RGCs) with the capacity to regenerate their severed processes are not yet well understood, but a number of biochemical correlates of the regeneration process have been observed, including

\footnotetext{
Received Apr. 20, 1992; revised July 15, 1992; accepted July 28, 1992.

We thank Linda K. Barthel for technical assistance with the immunocytochemistry, photomicroscopy, and confocal microscopy, Marianne R. Lewis for preparation of the explants, Michael $L$. Leski for advice on purification of p68/70, and Stephanie McWethy for assistance with preparation of the manuscript. This work was supported by NIH Grants EY 05947 (B.W.A.) and EY 04318 (P.A.R.) and NIH Training Grant 5 T32 GM07863 (G.R.W.).

Correspondence should be addressed to Dr. Bernard W. Agranoff, Neuroscience Laboratory Building, University of Michigan, 1103 East Huron, Ann Arbor, MI 48104-1687.

Copyright (c) 1993 Society for Neuroscience $0270-6474 / 93 / 130387-15 \$ 05.00 / 0$
}

increased RNA synthesis (Burrell et al., 1978, 1979; Dokas et al., 1981), metabolism of RNA precursors (Dokas et al., 1981; Kohsaka et al., 1981), and protein synthesis (Murray and Grafstein, 1969; Heacock and Agranoff, 1976; Giulian et al., 1980). Relative to total protein synthesis, the expression of a small number of proteins appears to be dramatically increased in regenerating RGCs (Heacock and Agranoff, 1976; Giulian et al., 1980; Heacock and Agranoff, 1982; Perry et al., 1985; PerroneBizzozero and Benowitz, 1987). The induction of these proteins may be related to the establishment of a growth state in regenerating neurons as is described in the "GAP," or growth-associated protein hypothesis (Skene and Willard, 1981a,b).

Heacock and Agranoff (1982) described an acidic protein doublet ( $\mathrm{pI}=4.8-4.9$ ) migrating at approximately $68-70 \mathrm{kDa}$ on SDS-PAGE that displays a markedly increased incorporation of ${ }^{35} \mathrm{~S}$-methionine following axotomy that is maintained during axonal regrowth (Agranoff and Ford-Holevinski, 1984). This protein, termed $\mathrm{p} 68 / 70$, has been detected in goldfish retina, optic nerve, and brain (Heacock and Agranoff, 1982; Perry et al., 1985; Perrone-Bizzozero and Benowitz, 1987) and is presumed to be synthesized by RGCs since it is axonally transported within the optic nerve (Heacock and Agranoff, 1982; Perry et al., 1985). Although the cellular function of p68/70 remains to be determined, its increased expression during nerve regeneration raises the possibility that its expression is related to the process of axonal regrowth.

Since the goldfish retina (Raymond Johns, 1977; Meyer, 1978; Raymond Johns and Fernald, 1981) and tectum (Meyer, 1978; Raymond and Easter, 1983) undergo neurogenesis throughout life, it was possible in the present experiments to investigate the possibility that $\mathrm{p} 68 / 70$ plays a role in neurogenesis as well as in regeneration. Although axonal regeneration and neurogenesis in adult goldfish are clearly separate processes, each involves axonal elongation, synapse formation, and synapse refinement, and may therefore share similar biochemical mechanisms, such as the induction of proteins with growth-related functions. The experiments reported here utilize a highly specific antibody to p68/70 to investigate the expression of p68/70 in the regeneration and de novo growth of the goldfish visual system, and the results suggest that $\mathrm{p} 68 / 70$ may play a general role in neuronal growth.

\section{Materials and Methods}

Animals. Adult goldfish (Carassius auratus, 6-9 cm; Grassy Forks Fisheries, Martinsville, IN) were housed in aerated tanks at $20 \pm 2^{\circ} \mathrm{C}$. Right optic nerve crush was performed intraorbitally under tricaine methanesulfonate anesthesia as previously described (Springer and Agranoff, 1977). Cross-reactivity of anti-p68/70 to various species was tested in 
adult rat (Sprague-Dawley strain), turtle (Chrysemys scripti elegans), frog (Xenopus laevis from Xenopus 1 , Brighton, MI), and 15 fish species (see Fig. 4 caption) that were obtained from local suppliers. New Zealand White rabbits (Oryctolagus cuniculus, $3-4 \mathrm{~kg}$ ) were used for the production of anti-p68/70 antibodies by Pel-Freez Biologicals (Rogers, AK)

p68/70 purification and anti-p68/70 production. To obtain $\mathrm{p} 68 / 70$ for antibody production, goldfish brain $(50-70 \mathrm{gm})$ was homogenized in 1 vol of $62.5 \mathrm{~mm}$ Tris- $\mathrm{HCl}$ buffer ( $\mathrm{pH} 6.8$ ) containing $1 \mathrm{~mm}$ phenylmethylsulfonyl fluoride and centrifuged at $13,000 \times g$ for $20 \mathrm{~min}$. The resulting pellet was washed twice by rehomogenization and recentrifugation, and the combined supernatant fractions were centrifuged at $100,000 \times g$ for $1 \mathrm{hr}$. The high-speed supernatant was then brought to $\mathrm{pH} 5.0$ by the addition of $20 \mathrm{~mm}$ sodium acetate (pH 4.0) and stirred at $4^{\circ} \mathrm{C}$ for $4 \mathrm{hr}$. Protein that precipitated during this step was removed by centrifugation at $13,000 \times g$ for $20 \mathrm{~min}$, and the supernatant was applied to a DEAE-Sephacel column equilibrated with $20 \mathrm{~mm}$ sodium acetate ( $\mathrm{pH} 5.0$ ). The column was washed with $20 \mathrm{~mm}$ sodium acetate (pH 4.0), and a p68/70-enriched fraction was eluted with $20 \mathrm{~mm}$ sodium acetate $(\mathrm{pH} 4.0)$ containing $0.1 \mathrm{M} \mathrm{NaCl}$. The $\mathrm{pH}$ of this fraction was adjusted to 6.0 with $\mathrm{NaOH}$ and the salt content was changed by adding 0.1 vol of $0.5 \mathrm{M} \mathrm{NaCl}, 10 \mathrm{mM} \mathrm{CaCl}, 10 \mathrm{mM} \mathrm{MgCl}_{2}, 10 \mathrm{~mm} \mathrm{MnCl}$, and $0.1 \%$ sodium azide. Glycoprotein contaminants in this fraction were then removed with a ConA-agarose column. The unretained protein was dialyzed against $10 \mathrm{~mm}$ ammonium bicarbonate, lyophilized, resuspended in $500-800 \mu \mathrm{l}$ of $200 \mathrm{~mm}$ ammonium formate, and applied to a TSK-3000SW HPLC gel filtration column that had been equilibrated in the same buffer. Fractions containing p68/70 were pooled lyophilized, and resuspended in electrophoresis sample buffer $(62.5 \mathrm{~mm}$ Tris- $\mathrm{HCl}, 10 \%(\mathrm{w} / \mathrm{v})$ glycerol, $2 \%(\mathrm{w} / \mathrm{v})$ SDS, $5 \%(\mathrm{v} / \mathrm{v}) \beta$-mercaptoethanol; $\mathrm{pH} 6.8$ ). Proteins were separated by SDS-PAGE on $6 \%$ gels without individual sample wells and visualized with $300 \mathrm{mM} \mathrm{CuCl}_{2}$ (Lee et al., 1987), and p68/70 was isolated by excising the corresponding bands from the gels. The gel slices containing p68/70 were destained in $0.5 \mathrm{~m}$ Tris, $0.5 \mathrm{~m}$ EDTA ( $\mathrm{pH} 9.0$ ), homogenized in stcrilc isotonic salinc, and injected subcutaneously into multiple sites along the backs of three rabbits for preparation of antisera, which were then affinity purified using a method modified from Olmsted (1981).

Since goldfish eggs contain a p68/70-like protein (Wilmot et al., 1987) that can be purified in large amounts using the same procedure as for brain p68/70 (M. L. Leski, personal communication), this tissue was used as a source for the p68/70 used in the affinity purification. Approximately $400 \mu \mathrm{g}$ of p68/70-like material was purified as described above except that the eluate from the DEAE column was dialyzed against $20 \mathrm{~mm}$ Tris- $\mathrm{HCl}(\mathrm{pH} 8.0)$ containing $0.1 \mathrm{M} \mathrm{NaCl}$ and then passed through $\mathrm{CuCl}_{2}$-charged iminodiacetic acid agarose (Sigma Chemical Co., St. Louis, MO; Kurecki et al., 1979). The flow-through of this column was collected and subjected to gel filtration HPLC as described above.

Approximately $200 \mu \mathrm{g}$ of p68/70-like material from goldfish cggs (100 gm) was applied to each of two SDS-polyacrylamide gels that had been prepared without individual sample wells. The p68/70-like material was visualized with $\mathrm{CuCl}_{2}$, excised, destained in EDTA, and transferred to nitrocellulose overnight at $7 \mathrm{~V} / \mathrm{cm}$ in a buffer consisting of $25 \mathrm{~mm}$ Tris, $192 \mathrm{~mm}$ glycine, $0.1 \%$ SDS, and $20 \%$ methanol (pH 8.3). The nitrocellulose blots were blocked for $1 \mathrm{hr}$ in TBS $(10 \mathrm{~mm}$ Tris, $150 \mathrm{~mm} \mathrm{NaCl}$; pH 7.4) containing $0.05 \%$ sodium azide and $1 \%$ bovine serum albumin (BSA), and then incubated with $3 \mathrm{ml}$ of crude antiserum diluted 1:20 in blocking buffer for $1-4 \mathrm{hr}$ at room temperature or overnight at $4^{\circ} \mathrm{C}$. The blots were then washed for $30 \mathrm{~min}$ in several changes of TBS containing $0.2 \%$ Triton $X-100$ and $0.05 \%$ sodium azide (TBS-Txa), rinsed briefly in TBS to remove detergent, and eluted with $2 \mathrm{ml}$ of 0.2 $\mathrm{M}$ glycine- $\mathrm{HCl}(\mathrm{pH} \mathrm{2.3)}$ for $2 \mathrm{~min}$. The eluate was immediately neutralized with Tris base, and the elution was repeated once more. The combined eluates were made $0.1 \%$ in BSA, and stored at $4^{\circ} \mathrm{C}$ while the blot affinity purification procedure was repeated 20 times. The eluates were brought to $0.4 \% \mathrm{BSA}$ and stored at $-70^{\circ} \mathrm{C}$. The affinity-purified antibody is referred to as anti-p68/70, and was used undiluted unless noted. The IgG concentration of anti-p68/70 was determined to be 0.72 $\mu \mathrm{g} / \mathrm{ml}$ by an ELISA using normal rabbit IgG (Sigma) as standard.

Sample preparation for electrophoresis. Tissues that were to be analyzed with one-dimensional SDS-PAGE were quickly removed from decapitated animals and were homogenized at $95-100^{\circ} \mathrm{C}$ in $10 \mathrm{vol}$ of prewarmed $62.5 \mathrm{~mm}$ Tris- $\mathrm{HCl}$ buffer $(\mathrm{pH} 6.8)$ containing $10 \%(\mathrm{w} / \mathrm{v})$ glycerol and $2 \%$ SDS. In the experiments represented in Figures 9-11, the homogenates were then cleared of residue by centrifugation for 15 $\mathrm{min}$ in a microfuge at $16,000 \times \mathrm{g}$. In the other experiments, the homogenates were first sonicated with an ultrasonic probe and then cen- trifuged in an airfuge at $100,000 \times g$ for $10 \mathrm{~min}$. Samples to be separated by two-dimensional gel electrophoresis (2-DGE) were homogenized in $10 \mathrm{vol}$ of $8 \mathrm{M}$ urea containing 5\% NP.40 and then centrifuged at 16,000 $\times g$ for $15 \mathrm{~min}$. Protein concentration was determined spectrophotometrically using the bicinchoninic acid method (Pierce Chemical Co., Rockford, IL; Smith et al., 1985).

Electrophoresis and immunoblotting. SDS-PAGE was performed as previously described (Laemmli, 1970) utilizing a 36.5:1 acrylamide: bisacrylamide ratio. Two-dimensional gel electrophoresis utilized a $\mathrm{pH}$ 4.5-6.8 isoelectric focusing gradient for the first dimension and SDSPAGE on $10 \%$ acrylamide gels for the second dimension. Following electrophoresis, samples that were to be analyzed by immunoblotting were transferred at $4^{\circ} \mathrm{C}$ to nitrocellulose (Schleicher and Schuell, Keene, $\mathrm{NH} ; 0.2 \mu \mathrm{m}$ pore diameter) for $12 \mathrm{hr}$ at $6 \mathrm{~V} / \mathrm{cm}$ in a buffer consisting of $25 \mathrm{~mm}$ Tris, $192 \mathrm{~mm}$ glycine, $0.02 \%$ SDS, and $20 \%$ methanol $(\mathrm{pH}$ 8.3). All subsequent steps were conducted at room temperature. The blots were blocked with $10 \%$ nonfat dried milk (NFDM) in TBS-Txa, briefly rinsed in TBS to remove excess blocking buffer, and incubated for $2 \mathrm{hr}$ in anti-p68/70 antibody diluted to $36 \mathrm{ng} / \mathrm{ml}$ in TBS-a (TBS plus $0.05 \%$ sodium azide) containing $1 \%$ BSA. Nonimmunc rabbit IgG (Sigma) was used at the same concentration as a control. Bound primary antibody was visualized with ${ }^{125}$ I-radiolabeled goat anti-rabbit IgG (25IGAR; 2-10 $\mu \mathrm{Ci} / \mathrm{mmol}$; ICN Biomedicals, Costa Mesa, CA). After the blots were washed for $30 \mathrm{~min}$ in three or four changes of TBS-Txa, they were incubated in $30 \mathrm{ml}$ of $1.5 \mu \mathrm{Ci} / \mathrm{ml}{ }^{125} \mathrm{~J}$-GAR diluted in TBS-Txa containing $1 \% \mathrm{BSA}$. The blots were washed in TBS-Txa as before, rinsed briefly in $\mathrm{H}_{2} \mathrm{O}$, air dried, and exposed to preflashed Kodak XAR x-ray film and an intensifying screen for $2-18 \mathrm{hr}$ at $-70^{\circ} \mathrm{C}$

To determine relative p68/70 content, four to six lanes of varying concentrations of purified goldfish brain p68/70 (5-80 ng in $25 \mu \mathrm{l})$ were run on each gel along with the samples to be assayed. The p68/70 standards were diluted in SDS-PAGE sample buffer that contained $0.1 \%$ protein (Dalton Mark VII molecular weight standards, Sigma) as carrier. Following autoradiography, the blot was aligned with the film and portions of the blot that corresponded to $\mathrm{p} 68 / 70$ were excised, counted on a gamma counter, and compared to a linear regression obtained from standards.

Explant culture and immunofluorescence. Retinal explants were prepared as previously described from fish that had received optic nerve crush 7-14 d previously (Landreth and Agranoff, 1979). Explants that had grown 7-9 d on poly-L-lysine-coated glass coverslips were examined with indirect immunofluorescence. The coverslips were rinsed for $2 \mathrm{~min}$ in TBS to remove the nutrient medium, fixed at $-20^{\circ} \mathrm{C}$ in AFA $(70 \%$ ethanol:formalin:acetic acid, 90:5:5) for $5 \mathrm{~min}$, and rinsed in TBS for $5 \mathrm{~min}$. Nonspecific binding was blocked with $10 \%$ NFDM in TBS-a, and the cultures were then rinsed for $2 \mathrm{~min}$ in TBS, immunostained with anti-p68/70 $(0.72 \mu \mathrm{g} / \mathrm{ml}$ in TBS-a plus $0.4 \%$ BSA $)$, and washed in TBS for $15 \mathrm{~min}$. In singlc-labcl experiments, an affinity-purified fluorescein isothiocyanate (FITC) conjugate of goat anti-rabbit IgG (FITCGAR; Sigma) that had been diluted 1:200 in TBS-a plus 1\% BSA was used to reveal bound primary antibody. The FITC-GAR was incubated with the explants for $1 \mathrm{hr}$, after which the coverslips were again washed in TBS, rinsed for $1 \mathrm{~min}$ in $\mathrm{H}_{2} \mathrm{O}$, and mounted on glass microscope slides with $50 \%(\mathrm{v} / \mathrm{v})$ glycerol in $0.1 \mathrm{M} \mathrm{Na}_{2} \mathrm{CO}_{3}$ buffer ( $\mathrm{pH} 9.0$ ) containing $0.4 \%$ p-phenylenediamine.

Explants processed for dual label immunofluorescence were conducted essentially as described above, except that 0.1 vol of anti-acetylated $\alpha$-tubulin (a mouse monoclonal IgG; Piperno and Fuller, 1985) was added to the anti-p68/70 rabbit antibody. Antigen-antibody complexes were visualized with tetramethylrhodamine isothiocyanate (TRITC)-conjugated donkey anti-mouse IgG and FITC-conjugated donkey anti-rabbit IgG that were diluted together in TBS containing $1 \%$ BSA. Both secondary antibodies (Jackson ImmunoResearch, West Grove, PA) were used at 1:20.

Tissue sectioning and immunocytochemistry. Tissues were fixed and cryoprotected using the method reported by Barthel and Raymond (1990), except that fixation was carried out in AFA rather than in paraformaldehyde. Sections $(6-12 \mu \mathrm{m})$ were cut at $-20^{\circ} \mathrm{C}$ on a Bright cryostat, thaw mounted on gelatin-subbed slides, and stored at $-70^{\circ} \mathrm{C}$ until they were further processed for immunocytochemistry.

The distribution of $\mathrm{p} 68 / 70$ in tissue sections was determined by indirect immunofluorescence utilizing a biotin-avidin-fluorescein detection method. Sections were air dried, rehydrated in TBS, and then incubated with 10\% NFDM in TBS-a for $1 \mathrm{hr}$. Anti-p68/70 was placed on the sections and allowed to bind overnight at $4^{\circ} \mathrm{C}$. After unbound primary antibody had becn removed with a $15 \mathrm{~min}$ wash in TBS, bio- 

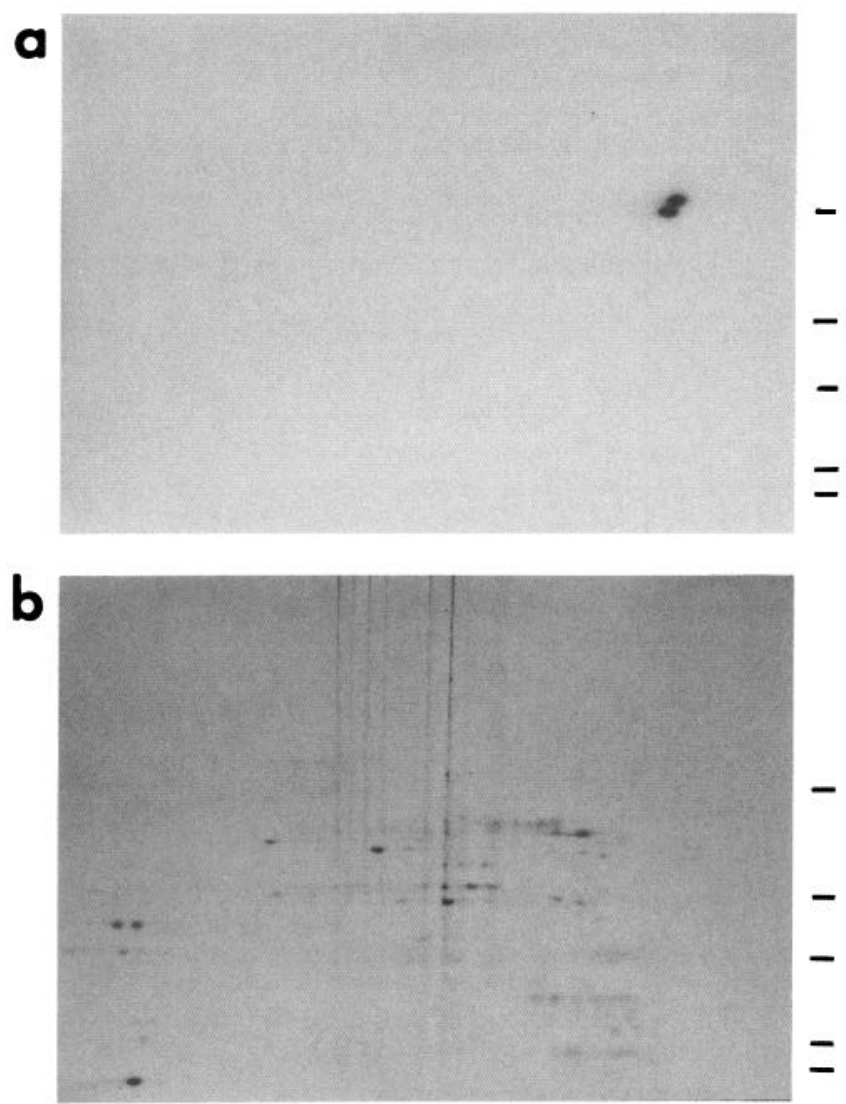

Figure 1. Specificity of anti-p68/70. Goldfish brain was homogenized at $95-100^{\circ} \mathrm{C}$ in $62.5 \mathrm{~mm}$ Tris- $\mathrm{HCl}$ buffer $(\mathrm{pH} 6.8)$ containing $10 \%(\mathrm{w} /$ v) glycerol and $2 \%$ SDS. $a$, Brain homogenate $(60 \mu \mathrm{g})$ was separated by 2-DGE, transferred to nitrocellulose, and incubated with anti-p68/70 IgG $(36 \mathrm{ng} / \mathrm{ml})$. Bound antibody was detected with ${ }^{125} \mathrm{I}-\mathrm{GAR}$ followed by autoradiography. Anti-p68/70 detects a $68-70 \mathrm{kDa}$ doublet with isoelectric points characteristic of p68/70. $b$, Coomassie blue-stained duplicate gel of the brain homogenate; p68/70 is barely visible in this gel. Markers indicate the migration of molecular weight standards (68, $43,36,29$, and $24 \mathrm{kDa}$ ). tinylated goat anti-rabbit IgG (Vector Laboratories, Burlingame, CA) diluted 1:200 in TBS-a containing 1\% BSA was incubated with the sections for $1 \mathrm{hr}$. Excess antibody was washed off with TBS for $15 \mathrm{~min}$, and the remaining bound antibody was visualized with a $1 \mathrm{hr}$ incubation of the sections in avidin-fluorescein (DCS grade; Vector) that had been diluted 1:25 in TBS-a plus 1\% BSA. Sections were rinsed and coverslipped as noted above.

In some experiments, the distribution of anti-p68/70 was compared to that of NN1, a monoclonal antibody that recognizes endothelial and presumptive microglial cells of the goldfish retina (Wagner and Raymond, 1991). After nonspecific binding sites were blocked as described above, sections were incubated overnight at $4^{\circ} \mathrm{C}$ in a combination of the two primary antibodies. NN1 in ascites fluid was used at 1:1000 and was diluted directly into the stock anti-p68/70 $(0.72 \mu \mathrm{g} / \mathrm{ml})$. Unbound antibodies were removed from the tissue sections with TBS, and the sections were incubated in biotinylated goat anti-rabbit IgG. After another wash in TBS, bound antibodies were revealed in a single incubation with TRITC-labeled donkey anti-mouse IgG (1:20) and avidin-fluorescein DCS $(1: 25)$ diluted in TBS plus $1 \%$ BSA. To determine cellular colocalization quantitatively, eight double-labeled sections from each of four fish were examined under the microscope at high power (400×; field diameter approximately $350 \mu \mathrm{m})$. Cells labeled by antip68/70, NN1, or both antibodies were counted in five high-power fields per section. Two of the fields, one in nasal retina and the other in temporal retina, sampled the peripheral retina starting just inside the germinal neuroepithelium. The remaining three fields sampled central retina at equidistant intervals.

Juvenile goldfish were injected intraocularly with sufficient 5 '-bromo$2^{\prime}$-deoxyuridine (BrdU) calculated to achieve a $50 \mu \mathrm{M}$ vitreal concentration (Knight and Raymond, 1990). Retinas were removed and processed $24 \mathrm{hr}$ later, and were analyzed for the cellular colocalization of BrdU and p68/70 immunoreactivity. The sections were first processed for p68/70 using the single-label method noted above, and then were processed for BrdU according to the method of Knight and Raymond (1990).

Immunofluorescent sections were typically photographed with a Leitz Aristoplan compound microscope equipped with epifluorescence and Nomarski optics. In one experiment, a laser confocal microscope (BioRad MRC 600 with a Nikon Diaphot) was used.

\section{Results}

Antibody characterization and tissue distribution of p68/70. The affinity-purified polyclonal antibody specifically recognized two proteins at 68 and $70 \mathrm{kDa}$ in two-dimensional immunoblots of goldfish brain homogenates (Fig. 1). These two proteins have isoelectric points that are characteristic of p68/70. In one-di-



$\begin{array}{lllllllll}1 & 2 & 3 & 4 & 5 & 6 & 7 & 8 & 9\end{array}$ $\begin{array}{lllllllll}1 & 2 & 3 & 4 & 5 & 6 & 7 & 8 & 9\end{array}$
Figure 2. Distribution of anti-p68/70 immunoreactivity in goldfish tissue homogenates (30 $\mu \mathrm{g} / \mathrm{lane})$. Autoradiograms are shown that correspond to blots incubated with $36 \mathrm{ng} / \mathrm{ml}$ anti-p68/ $70($ a $)$ or nonimmune $\operatorname{IgG}($ b). Lane 1 , brain; lane 2, spinal cord; lane 3, retina; lane 4, liver; lane 5, muscle; lane 6, skin; lane 7, testis; lane 8, egg; lane 9, ovary. In all tissues, anti-p68/70 specifically recognized bands at 68 and 70 $\mathrm{kDa}$. In addition, skin contained a slightly cross-reactive low-molecularweight $(<25 \mathrm{kDa})$ band (arrowhead, lane 6 ). Egg and ovary contained bands that were observed in the presence of both anti-p68/70 $(a)$ and nonimmune IgG (b), and separate experiments (not shown) indicated that these nonspecifically labeled bands were also labeled in the absence of primary antibody. Molecular weights are indicated at 116 , $97.4,68,43$, and $29 \mathrm{kDa}$. 

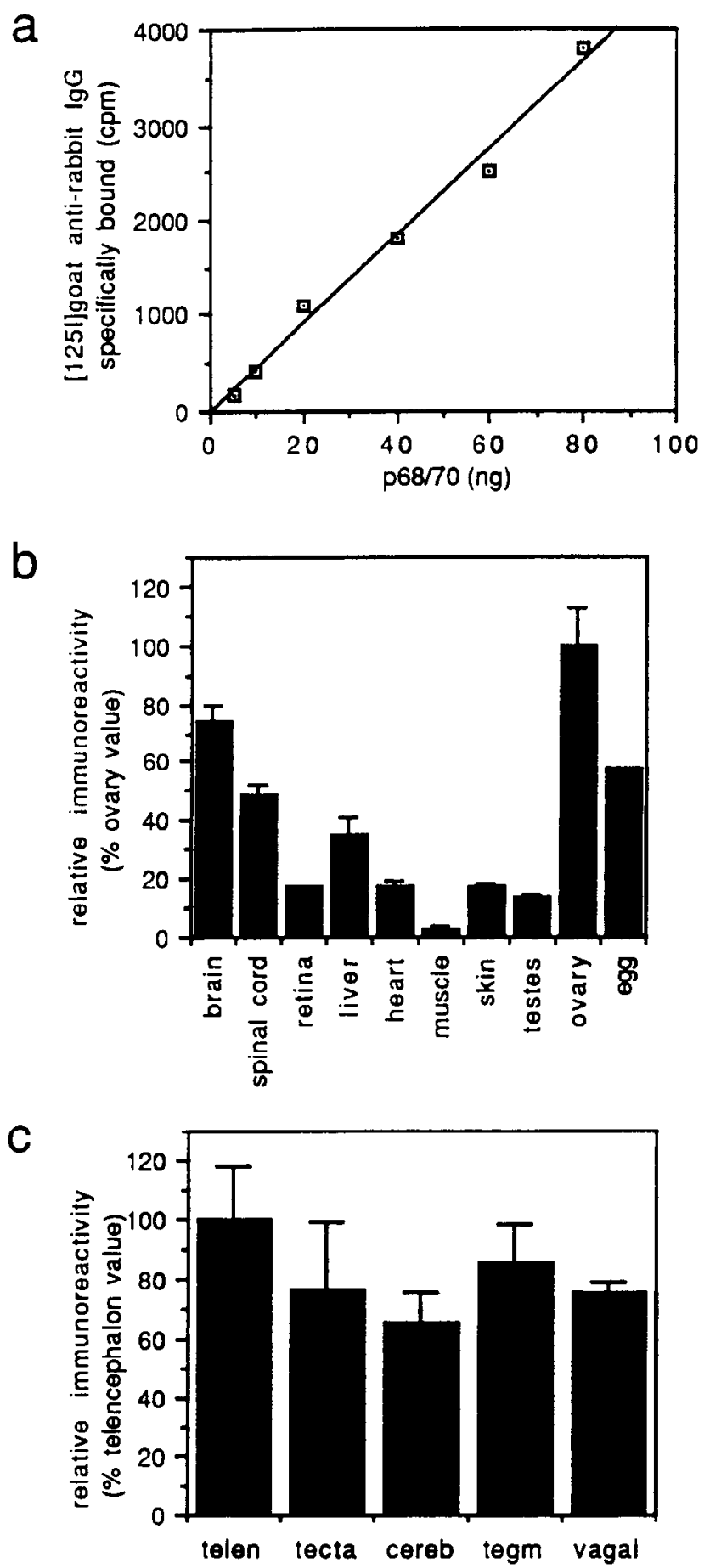

Figure 3. Relative anti-p68/70 immunoreactivity of goldfish tissues and brain regions determined by quantitative immunoblot assays. Samples were prepared, electrophoresed on one-dimensional gels, and incubated with anti-p68/70 as described in the previous figures. Other procedures were as described in Materials and Methods. $a$, Standard curve demonstrating the relationship between the amount of purified p68/70 applied per lane and the amount of bound 125 I-GAR. Autoradiograms were used to determine the $68-70 \mathrm{kDa}$ region of the blot, which was then excised and counted in a gamma counter. Nonspecific binding to nitrocellulose was less than $10 \%$ of the total binding, and was subtracted from the total $\mathrm{cpm}$ to yicld specific cpm. Lincar correlation coefficients ranged from 0.95 to 0.99 , and were typically $>0.97$. $b$, Relative immunoreactivity of goldfish tissues. The immunoreactivity (cpm of bound ${ }^{125} \mathrm{I}-\mathrm{GAR}$ ) of the $68-70 \mathrm{kDa}$ bands in tissue homogenates was compared with purified p68/70 that had been run on the same gel. Values were normalized to ovary, which contained the greatest amount mensional immunoblots, anti-p68/70 recognized a $68-70 \mathrm{kDa}$ doublet in all tissues; no other immunoreactive bands were noted except in skin, where slight cross-reactivity to a lowmolecular-weight ( $<25 \mathrm{kDa}$ ) band was observed (Fig. 2). The relationship of this band to p68/70 is not known, but it is unlikely to be a proteolytic fragment of the doublet resulting during tissue preparation, since the tissue samples were homogenized under denaturing conditions $\left(95-100^{\circ} \mathrm{C}\right.$ in $2 \%$ SDS-containing buffer). Since the band was present only in skin and was only weakly recognized by anti-p68/70, this cross-reactivity is unlikely to affect the principal results reported here.

An immunoblot was developed and used to determine the relative amount of p68/70 immunoreactivity contained in 10 different goldfish tissues and 5 different goldfish brain regions. As shown in Figure $3 a$, the amount of ${ }^{125}$ I-GAR bound to the 68-70 kDa region of the nitrocellulose blot was linearly related to the amount of p68/70 (5-80 ng) applied to the gel. The tissue homogenates contained anti-p68/70 immunoreactivity that varied over a 30 -fold range (Fig. $3 b$ ). Ovary contained the most immunoreactivity per milligram of tissue protein; muscle contained the least. Within brain, anti-p68/70 immunoreactivity was relatively evenly distributed among the five subregions examined (Fig. 3c).

Phylogenetic distribution of anti-p68/70 immunoreactivity. Anti-p68/70 cross-reacted strongly with brain homogenates from five of the fish species tested, reacted weakly with four other fish species, and did not recognize amphibian, reptilian, or mammalian spccics (Fig. 4). A $43 \mathrm{kDa}$ band was recognized in lamprey (Fig. 4a, lane 1); otherwise, all of the bands recognized by anti-p68/70 were $65-74 \mathrm{kDa}$. Three of the five fish species that contained strongly cross-reactive proteins belong to the minnow/carp family (Cyprinidae); the others belong to the sucker family (Catostomidae) and the loach family (Cobitidae). These three families all belong to the order Cypriniformes. Zebrafish, which is also classified as a Cyprinidae, was only weakly immunoreactive (Fig. 4a, lane 5). Lemon tetra, which belongs to a different order (Characiformes), was also weakly immunoreactive. One of the two catfish (order Siluriformes) species tested showed weak cross-reactivity and was the only species other than goldfish that contained an immunoreactive doublet.

Localization of anti-p68/70 immunoreactivity in goldfish retina. Indirect immunofluorescence revealed anti-p68/70 binding to the inner plexiform layer (IPL), ganglion cell layer (GCL), optic fiber layer (OFL), and scattered cells throughout the retina (Fig. 5). The OFL was less intensely labeled than the IPL and GCL. The specificity of binding was confirmed by the lack of immunofluorescence when the antibody had been preincubated with excess purified brain p68/70 and when nonimmune IgG was used in place of anti-p68/70 (Fig. 5a,b). Within the IPL, immunofluorescence was coarsely punctate and was slightly brighter in sublamina 3 (defined according to Ramón y Cajal, 1972) compared with the remaining IPL. Cell bodies in the GCL were immunoreactive but were often difficult to discern since their intensity of labeling matched that of the surrounding IPL.

\footnotetext{
of anti-p68/70 immunoreactivity. $c$, Distribution of immunoreactivity in homogenates of five goldfish brain regions: telencephalon (telen), optic tecta (tecta), cerebellum (cereb), midbrain tegmentum (tegm), and vagal lobes (vagal). In $b$ and $c$, the values represent the mean \pm SEM for three separate samples of each tissue or brain region (SEMs for retina and egg were minute).
} 
Nevertheless, the vast majority of somata in this layer appeared to be labeled by anti-p68/70.

Anti-p68/70 immunoreactivity in the retina varied along the central-peripheral axis, with central retina being less immunoreactive than peripheral retina. The gradient of anti-p68/70 immunoreactivity appeared continuous throughout most of the retina, but antibody binding increased dramatically at the peripheral margin as shown in Figure 6. In this region, the immunofluorescence of the inner three layers of the retina was much more intense than in central retina. The inner nuclear layer (INL), outer plexiform layer (OPL), and outer nuclear layer (ONL), which are not immunoreactive throughout most of the retina, were reactive immediately adjacent to the germinal neuroepithelium, which was also intensely labeled by anti-p68/70.

Figure 7 demonstrates the anti-p68/70 immunoreactivity of the scattered retinal cells mentioned above. Many of the cells that were recognized by anti-p68/70 (anti-p68/70+ cells) were also stained by the monoclonal antibody NN1 (Fig. 7a,b), which recognizes microglia and endothelial cells in the retina (Wagner and Raymond, 1991). Within the retina, the distribution of cells that were labeled by both anti-p68/70 and NN1 is summarized in Figure $7 c$. NN1 ${ }^{+}$cells were found throughout the retina, and most of these cells also stained with anti-p68/70. Cells that were recognized by anti-p68/70 but not NN1 occurred almost exclusively in the ONL and (less frequently) in the INL. The antip68/70+, $\mathrm{NN}^{-}$cells in the INL resembled ganglion cells in their morphology and were located only on the innermost boundary of the INL. These are likely to be displaced ganglion cells, or "Dogiel cells," which constitute a small percentage of the total ganglion cell population in goldfish (Hitchcock and Easter, 1986). In the ONL, the anti-p68/70+, NN1- cells were found more often in peripheral than in central retina. The nuclei of these cells were most often positioned in the inner and middle portion of the ONL, and many of the cells had radial processes spanning the ONL. These characteristics of the anti-p68/70+, $\mathrm{NN}^{-}$- cells in the ONL suggest that they are rod precursors and/or recently born rods.

To determine if any of the anti-p68/70+ cells were mitotically active, in one experiment BrdU was administered intraocularly $24 \mathrm{hr}$ prior to tissue processing, and the colocalization of antip68/70 immunoreactivity and anti-BrdU immunoreactivity was then examined with double immunofluorescence (Fig. 8). Antip68/70 immunoreactivity and anti-BrdU immunoreactivity colocalized in some, but not all, of the anti-p68/70+ cells in the ONL. All of the anti-BrdU labeled cells in the ONL were antip $68 / 70^{+}$, as were the germinal neuroepithelial cells that were labeled by anti-BrdU (not shown).

Response to optic nerve crush. The amount of anti-p68/70 immunoreactivity in retinas following optic nerve crush increased relative to control (C) retina (Fig. 9). As judged by quantitative immunoblot assay, the increase was maximal (threefold) at $48 \mathrm{~d}$ postcrush (PC), and declined to a near-normal value by $104 \mathrm{~d}$ (Fig. 9a). As shown in Figure $9, b$ and $c$, the most dramatic difference in the anatomical distribution of antip68/70 immunoreactivity was observed in the somata of the RGCs, which were more intensely immunoreactive following axotomy.

Although ganglion cell somata in $\mathrm{C}$ retinas were generally not strikingly immunoreactive, in a single case, two hypertrophied ganglion cells displaying intense anti-p68/70 immunoreactivity were noted in a retina taken from a nonaxotomized fish; one of these cells is shown in Figure 10. The two unusual cells were


Figure 4. Immunoreactive proteins in brain homogenates of a variety of species. Homogenates were prepared from fresh tissue of all species other than Torpedo, which had been frozen on dry ice upon removal and stored at $-70^{\circ} \mathrm{C}$ until use. The homogenates were analyzed for antip68/70 immunoreactivity as indicated in Figure 1 except they were separated by one-dimensional SDS-PAGE. $a$, Autoradiogram demonstrating that anti-p68/70 recognizes proteins from several fish species but not from tetrapods. Lane 1, lamprey (Petromyzon marinus); lane 2, electric ray (Torpedo californica); lane 3, goldfish (Carassius auratus); lane 4, flat-head minnow (Pimphales vigilax); lane 5, zebrafish (Brachydanio rerio); lane 6, African clawed frog (Xenopus laevis); lane 7, redeared turtle (Chrysemys scripti elegans); lane 8, rat (Rattus norwegicus, Sprague-Dawley strain). In addition to the 68-70 kDa doublet in goldfish, anti-p68/70 recognizes a single $69 \mathrm{kDa}$ band in minnow and zebrafish and a $43 \mathrm{kDa}$ band in lamprey. The reaction of these bands was specific for anti-p68/70, as none were labeled when nonimmune IgG was substituted for anti-p68/70 IgG. The faint bands at approximately $55 \mathrm{kDa}$ appear to represent nonspecific binding of ${ }^{125}$ I-GAR since they were also labeled when the blots were incubated in ${ }^{125}$ I-GAR alone. $b$, Detailed analysis of the distribution of anti-p68/70 cross-reactivity among actinopterygian fish species. The $60-80 \mathrm{kDa}$ region of the autoradiogram is shown; cross-reactivity was not detected outside this region. Lane 1, gar (Lepisosteus sp.); lane 2, rainbow trout (Salmo salmo); lane 3, lemon tetra (Hyphessobrycon pulchripinnis); lane 4, clown barb (Barbodes everetti); lane 5, goldfish (Carassius auratus); lane 6, flat-head minnow (Pimphales vigilax); lane 7 , sucker (Hypentelium nigricana); lane 8 , loach (Misgurnus anguillicaudatus); lane 9, armored catfish (Corydoras aeneus); lane 10, naked catfish (Pimelodus albofasciatus); lane 11, guppy (Poecilia reticulata); lane 12, green sunfish (Lepomis cyenellus); lane 13, sculpin (Cottis bairdi). Species in the suborder Cyprinoidei (lanes 4-8) show the strongest cross-reactivity to anti-p68/70. Slight cross-reactivity is also apparent in the tetra (lane 3) and pictus catfish (lane 10), which is the only species other than goldfish in which an immunoreactive doublet rather than single band was detected. 



PE

ONL

OPL

INL

I P L

GCL

Figure 5. Distribution of anti-p68/70 immunoreactivity in goldfish retina. Sections from the same retina were incubated in either nonimmune IgG $(a)$, anti-p68/70 that had been preabsorbed with a 500 -fold excess of purified p68/70 (b), or anti-p68/70 (c). A corresponding retinal section is shown with differential interference contrast (Nomarski) optics in $(d)$. The most immunoreactive retinal layers are the IPL and the GCL. The scattered immunoreactive cells were observed throughout the retina. The pigmented epithelium ( $P E)$ lies outside of the neural retina. Within the IPL, immunofluorescence is brightest in sublamina 3 (arrowheads, c). Scale bar, $25 \mu \mathrm{m}$. 


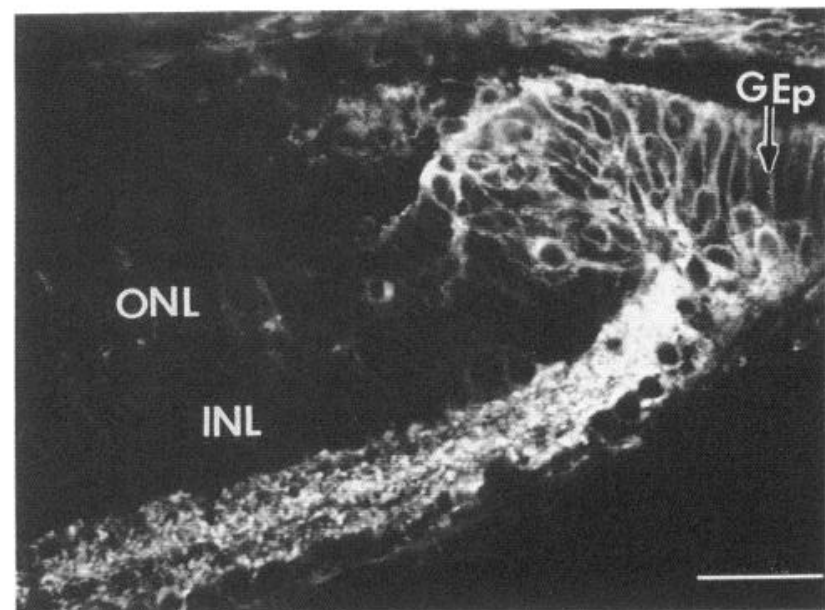

Figure 6. Anti-p68/70 immunofluorescence of the peripheral retina. This image of an immunolabeled $12-\mu \mathrm{m}$-thick retinal section was obtained by confocal microscopy. $G E p$, germinal neuroepithelium. Immunofluorescence in the ONL and INL is apparent only in the region of the retina adjoining the germinal neuroepithelium. Immunofluorescence of the IPL occurs throughout the entire retina but is increased near the germinal neuroepithelium. Scale bar, $25 \mu \mathrm{m}$.
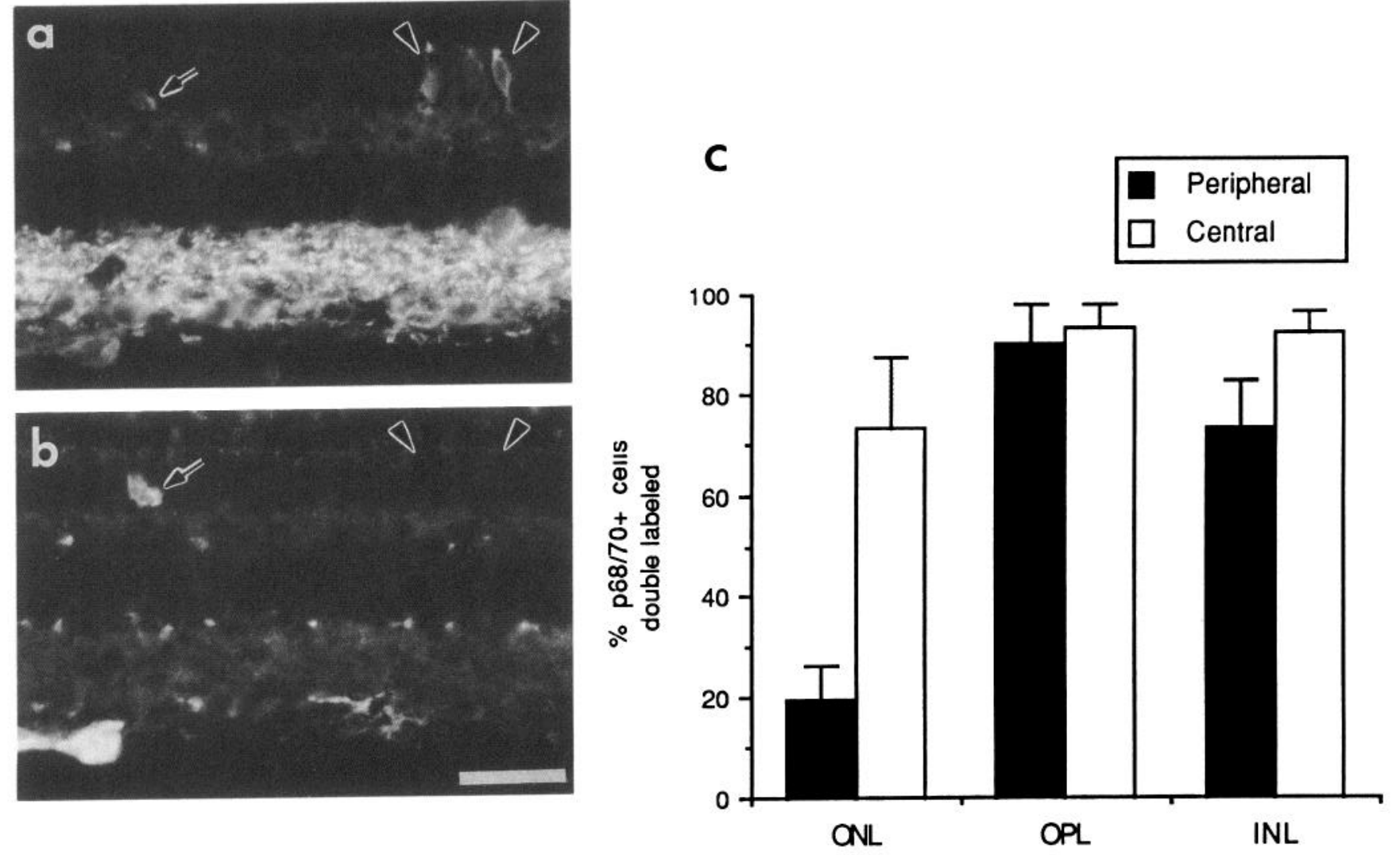

Retinal Layer seen in two of eight separate sections analyzed from this retina. Both cells were located approximately $20 \%$ of the distance from the peripheral margin to the optic disk. Over the course of the experiments reported here, an average of five sections from approximately 20 nonregenerating retinas were examined for anti-p68/70 immunoreactivity; this retina was the only one that possessed a ganglion cell with these characteristics. Although the reason for the expression of this "regenerating" phenotype is not known, the fact that the surrounding RGCs appear normal suggests that the signal for upregulation of $\mathrm{p} 68 / 70$ is discrete rather than disseminated.

As in retina, anti-p68/70 immunoreactivity increased in regenerating optic nerve (Fig. 11). The increase in immunoreactivity in homogenates of optic nerve was first apparent at $18 \mathrm{~d}$ and remained elevated at approximately the same level (over 1.5 -fold) for the remaining time points (up to $104 \mathrm{~d} \mathrm{PC}$ ). In cross sections of $\mathrm{C}$ optic nerve, immunolabeling with anti-p68/ 70 was observed primarily within the glial cells that surround the axonal bundles (Fig. 11b). Anti-p68/70 also appeared to label axons lightly within these bundles. In a comparable section of $24 \mathrm{~d}$ PC optic nerve that was distal to the crush site, nerve fibers stained by anti-p68/70 appeared both more numerous and more immunoreactive (Fig. 11c).
ONL

INL

Figure 7. Double immunofluorescence of retinal sections. The distributions of anti-p68/70 immunoreactivity $(a)$ and NN1 immunoreactivity $(b)$ were revealed in a single section with fluorescein and rhodamine detection methods, respectively. A cell in the ONL that is labeled by both antibodies is indicated by the arrows. Like many (but not all) colabeled cells, this cell is labeled less intensely with anti-p68/70 than with NN1. Portions of two other colabeled cells, which presumably lie mostly in another plane of section, can be seen below this cell. The arrowheads denote a region containing three cells that are anti-p $68 / 70^{+}$but NN1-. Endothelial cells, which are strongly labeled with NN1 (see capillary at the vitreal surface), are weakly recognized by anti-p68/70. Scale bar, $20 \mu \mathrm{m}$. $c$, Distribution of anti-p68/70+, NN1+ cells within the retina. Values are expressed as the mean \pm SEM $(n=4$ fish) of the percentage of anti-p68/70+ cells that are also recognized by NN1. Only the ONL displays a significant difference between the peripheral and central retina $\left(\chi^{2}\right.$ analysis of pooled data; $\left.\mathrm{gx}^{2}=89.1 ; p<0.0001\right)$. There are many p68/70+ cells in the peripheral ONL that are NN1-. These cells may be new rod or rod precursor cells (see Results and Discussion). 
Figure 8. a, Photomicrograph (Nomarski optics) of a retinal section taken from a fish that had received an intraocular injection of BrdU $24 \mathrm{hr}$ previously and was used to assess the codistribution of BrdU incorporation and anti-p68/70 immunoreactivity. The boxed area indicates the region shown in $b$ and $c$. $b$, Anti-p68/70 immunoreactivity. $c$, Anti-BrdU immunoreactivity. All cells that had incorporated BrdU were anti-p68/70+, but not all of the anti-p68/70+ cells had incorporated BrdU. Note the nonspecific fluorescence of the cone photoreceptors. Scale bars, $20 \mu \mathrm{m}$.
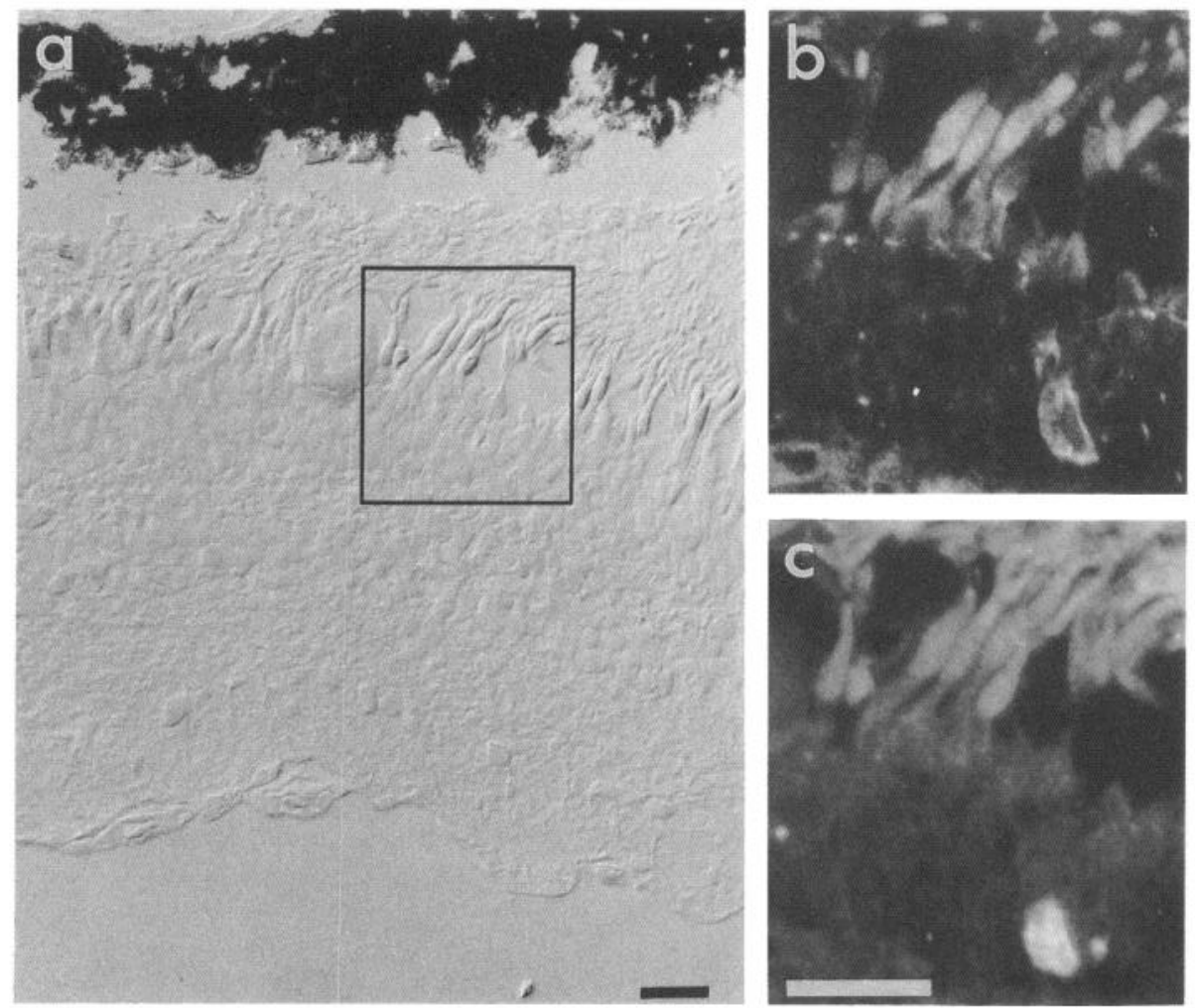

Figure 12 depicts the changes in anti-p68/70 immunoreactivity that occur in the tectum following axotomy. A slight increase in the PC:C ratio of p68/70-like immunoreactivity in tectal homogenates was apparent during regeneration. The increase appears maximal at $48 \mathrm{~d}$, but the variability at this time point was large. Nevertheless, a dramatic increase in the immunoreactivity of the regenerating optic nerve fibers was evident in tissue sections of $28 \mathrm{~d}$ PC fish (Fig. 12b,c). In transverse sections through $\mathrm{C}$ tectum, the stratum opticum (SO) and stratum fibrosum et griseum superficiale (SFGS), which are the a

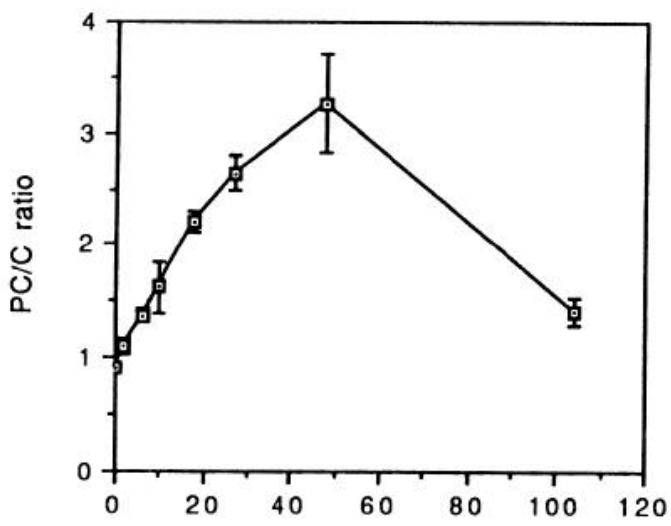

days postcrush
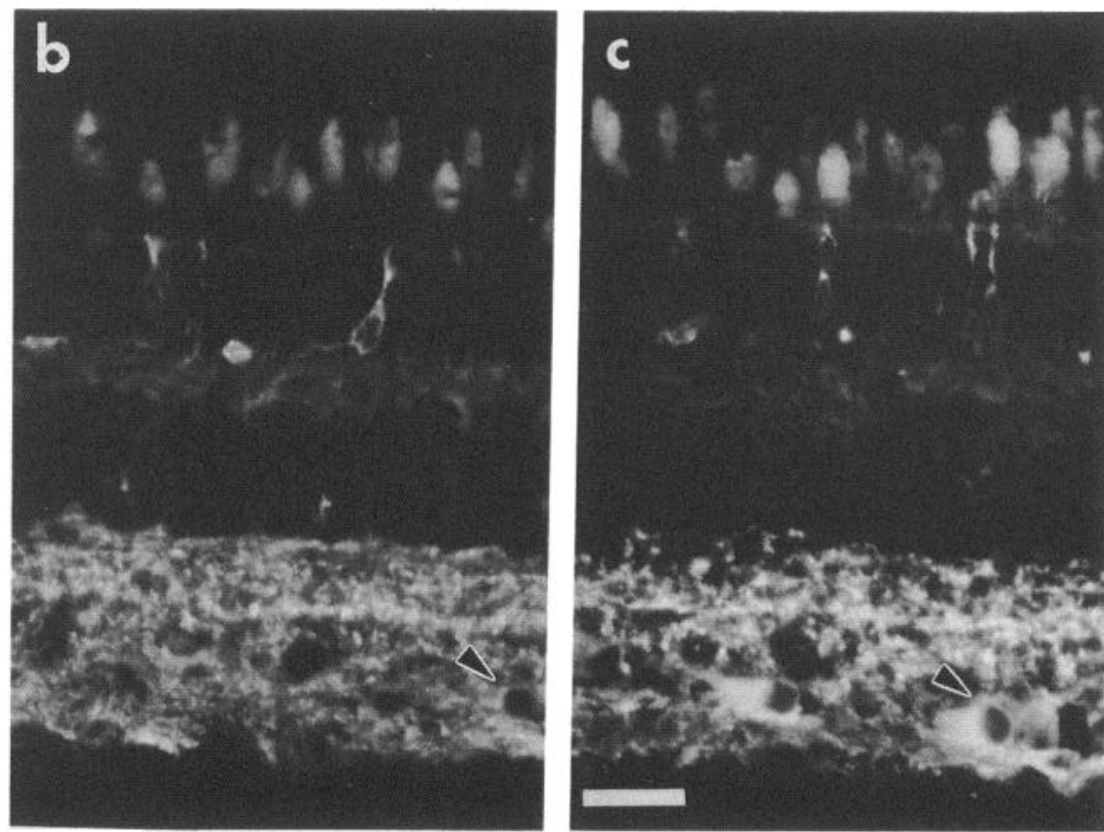

Figure 9. Anti-p68/70 immunoreactivity in the retina following optic nerve crush. $a$, PC:C ratio of anti-p68/70 immunoreactivity of retinal homogenates. Quantitative immunoblot assays were performed as described under Materials and Methods. Values represent the mean \pm SEM for three to six fish per time point. The change in the PC:C ratio over time was significant (one-way ANOVA, $F_{7,29}=17.716, p<0.0001$ ). $b$, Immunofluorescence of $\mathrm{C}$ retina taken from a fish that received unilateral optic nerve crush $14 \mathrm{~d}$ previously. $c$, Immunofluorescence of PC retina from the same fish. Arrows indicate ganglion cell somata, which are difficult to discern in the $\mathrm{C}$ retina but are conspicuous in the PC retina as a result of increased immunofluorescence. The fluorescence of the cone outer segments seen in the top portion of $b$ and $c$ is due to autofluorescence. Scale bar, $20 \mu \mathrm{m}$. 


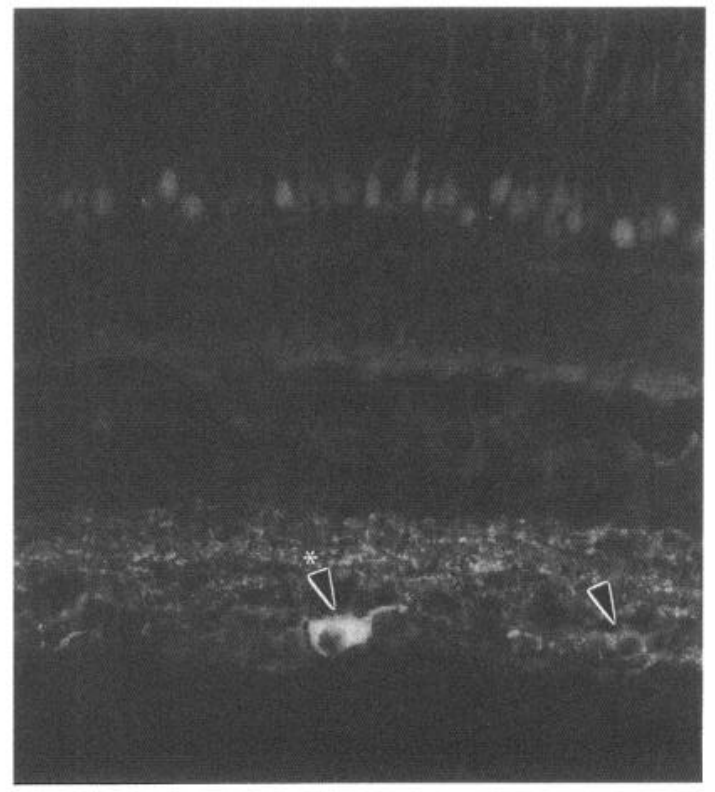

Figure 10. One of only two ganglion cells observed in a $\mathrm{C}$ retina that appeared similar to those from regenerating retina (arrowhead with asterisk). A neighboring ganglion cell with a more typical phenotype is indicated by the other arrowhead.

retinorecipient layers of the tectum, were only faintly labeled with anti-p68/70. In contrast, the SO and SFGS of the PC tectum were filled throughout with intensely immunoreactive fibers. Both $\mathrm{C}$ and PC tecta exhibited bright immunofluorescence in the stratum marginale (SM) and light, fiber-like immunoreactivity in the lower portion of the stratum griseum centrale (SGC).
Fiber bundles that coursed obliquely through the stratum periventriculare (SPV) were prominently labeled in both C and PC tectum, but the cell bodies of the periventricular neurons within the SPV were unlabeled except at the caudal tectal margin (see below). In addition to these neuronal elements, blood vessels were lightly immunofluorescent and the meningeal covering of the brain was moderately fluorescent.

Immunocytochemistry of the caudal tectum. Anti-p68/70 immunofluorescence was brighter at the caudal margin of the tectum than in the remaining tectum (Fig. 13). A rostrocaudal gradient of anti-p68/70 immunoreactivity was particularly evident in the periventricular neurons, which exhibit immunoreactivity at the caudal edge but not the rest of the tectum. The increased immunolabeling of the margin did not occur in rostral tectum.

Explant immunofluorescence. Neurites from retinal explants that had grown 7-9 d in culture were reacted with anti-p68/70 and found to exhibit strong immunofluorescence (Fig. 14). The pattern of neurite staining with anti-p68/70 closely reflected their appearance in phase-contrast images and contrasted to the linear staining pattern that was obtained with an anti-acetylated $\alpha$-tubulin antibody (Fig. 14a-c). Within individual neurites, antip68/70 immunoreactivity was concentrated around phase-dense intracellular organelles but was also present in the intervening neurite segments (Fig. 14f,g). Figure $14 g$ also shows the immunolabeling of small extensions that branched from the neurites and appeared to anchor the neurites to the substrate. The labeling of neuritic extensions was regularly spaced and punctate. Immunoreactivity to anti-p68/70 extended into the growth cones at the tips of individual and fasciculated neurites and also labeled the growth cone filopodia, which appeared similar to the more proximal neuritic extensions (Fig. 14h-k).

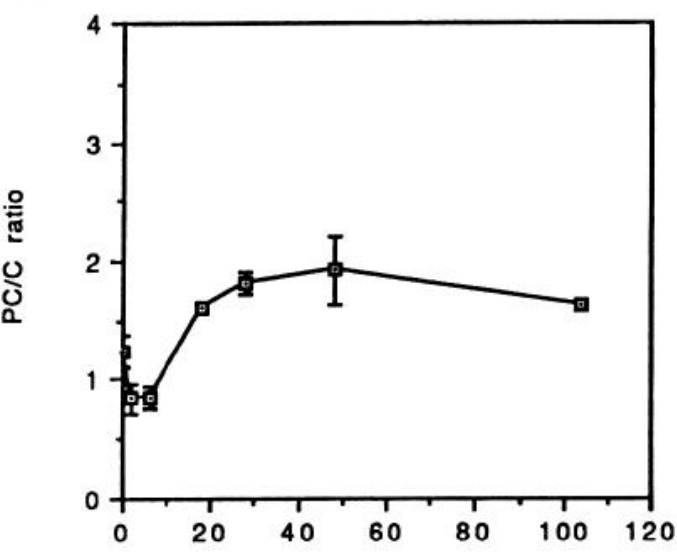

days postcrush
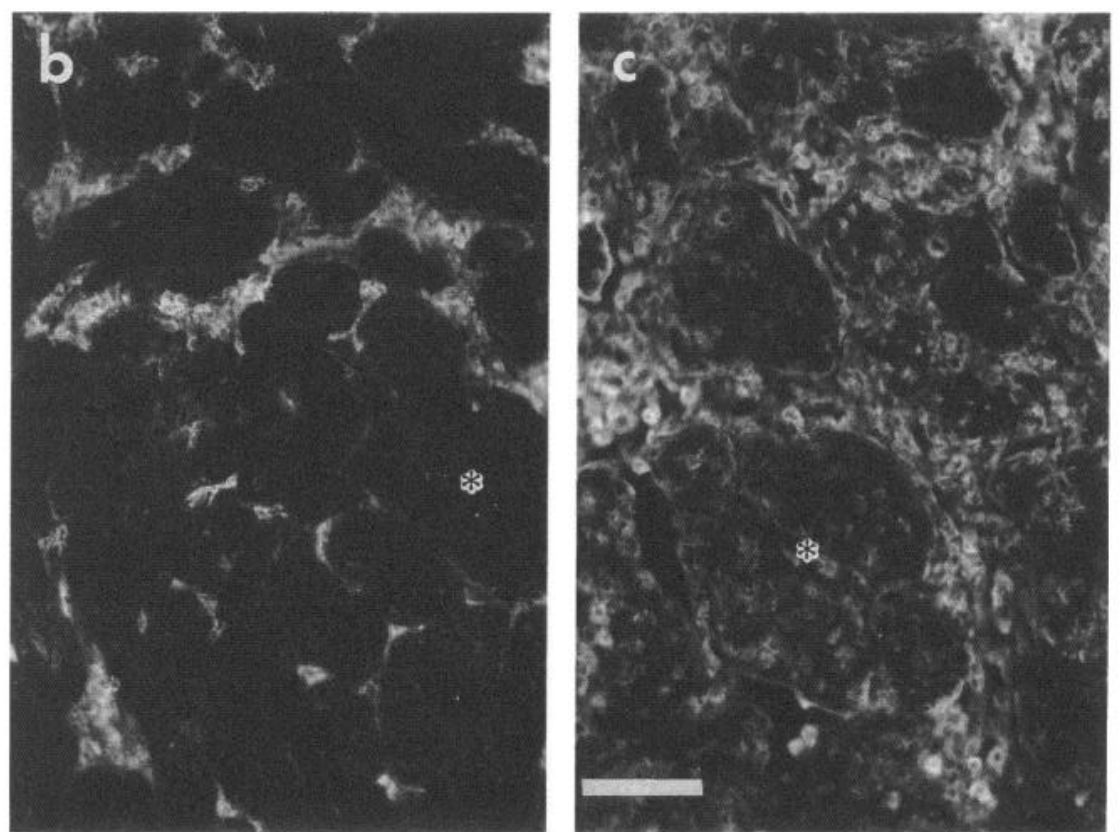

Figure 11. Anti-p68/70 immunoreactivity in the optic nerve following optic nerve crush. $a$, The PC:C ratio of anti-p68/70 immunoreactivity of optic nerve homogenates. Quantitative immunoblot assays were performed as described under Materials and Methods. Values represent the mean $\pm \mathrm{SEM}$ for three to five fish per time point. The change in the PC:C ratio over time was significant (one-way ANOVA, $F_{7.26}=8.5, p<0.0001$ ). $b$, Immunofluorescence of $\mathrm{C}$ optic nerve taken from a fish that received unilateral optic nerve crush $24 \mathrm{~d}$ previously. Immunoreactivity of the axonal bundles (asterisk) is much lower than the surrounding glia. $c$, Immunofluorescence of PC optic nerve from the same fish. Immunoreactivity of the axonal bundles is increased at this time point (asterisk). Scale bar, $50 \mu \mathrm{m}$. 
a

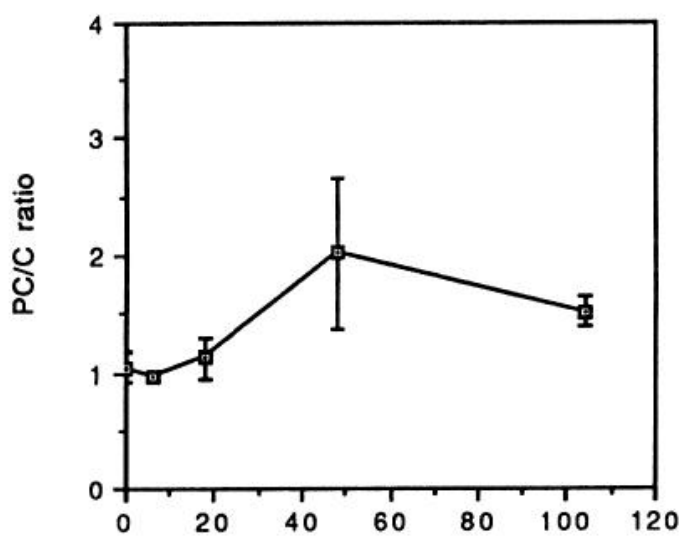

days postcrush
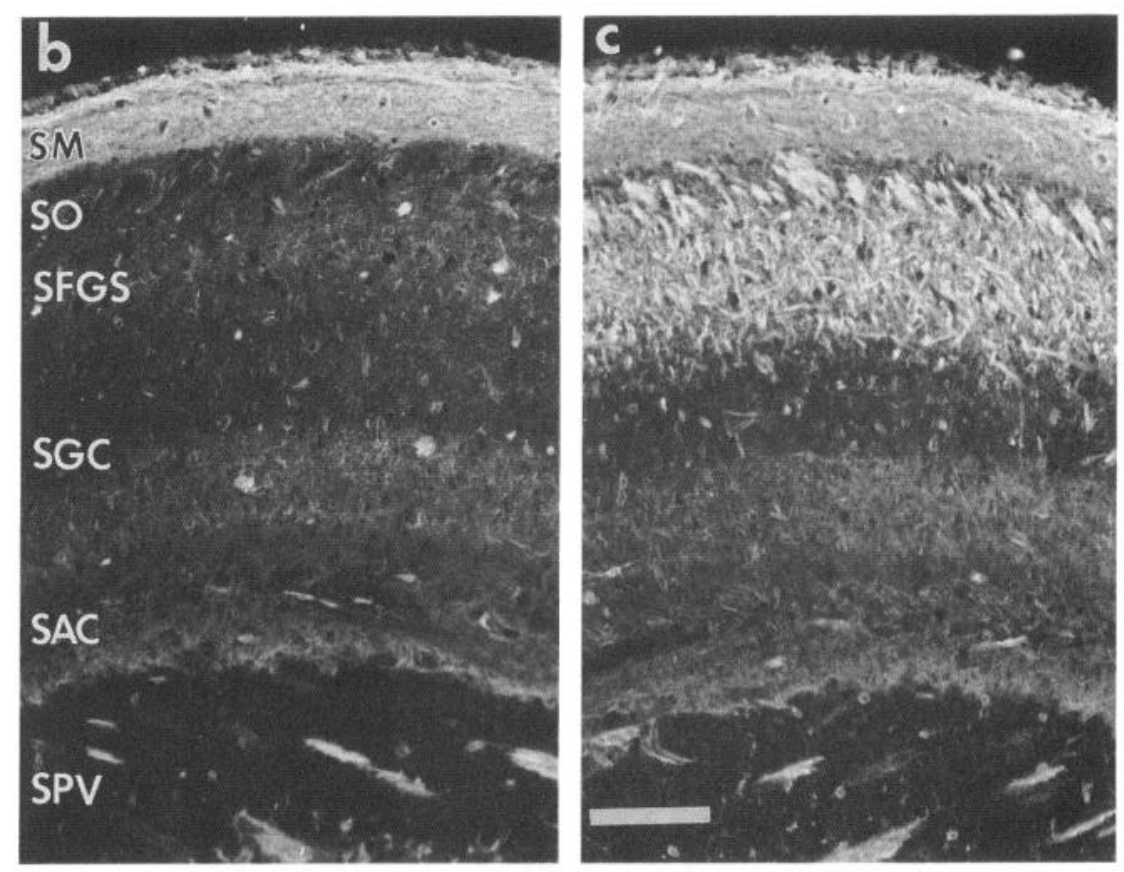

Figure 12. Anti-p68/70 immunoreactivity in the tectum following optic nerve crush. $a$, The PC:C of anti-p68/70 immunoreactivity of tectal homogenates. Quantitative immunoblot assays were performed as described under Materials and Methods. Values represent the mean \pm SEM for three or four fish per time point. The change in the PC:C ratio over time was not significant (see Results). $b$, Immunofluorescence of $\mathrm{C}$ tectum taken from a fish that received unilateral optic nerve crush $28 \mathrm{~d}$ previously. $c$, Immunofluorescence of PC tectum from the same fish. These transverse sections were taken from a mid-tectal level. Scale bar, $100 \mu \mathrm{m}$.

\section{Discussion}

By use of an affinity-purified polyclonal antibody, the present studies have confirmed that p68/70 is indeed a marker of neuronal regeneration in adult goldfish, that the amount of the doublet is increased in the visual system during regeneration, and that this protein is most prominent in ganglion cell somata and axons. Expression of p68/70 does not appear to be confined to the nervous system, and in the nervous system it is not restricted to regenerating axons, since evidence is presented that indicates a role for the doublet protein in neurogenesis as well.

The visual system of adult goldfish is an instance of a CNS tissue that displays neurogenesis in adulthood. The goldfish retina grows throughout life by increases in both cellular size and
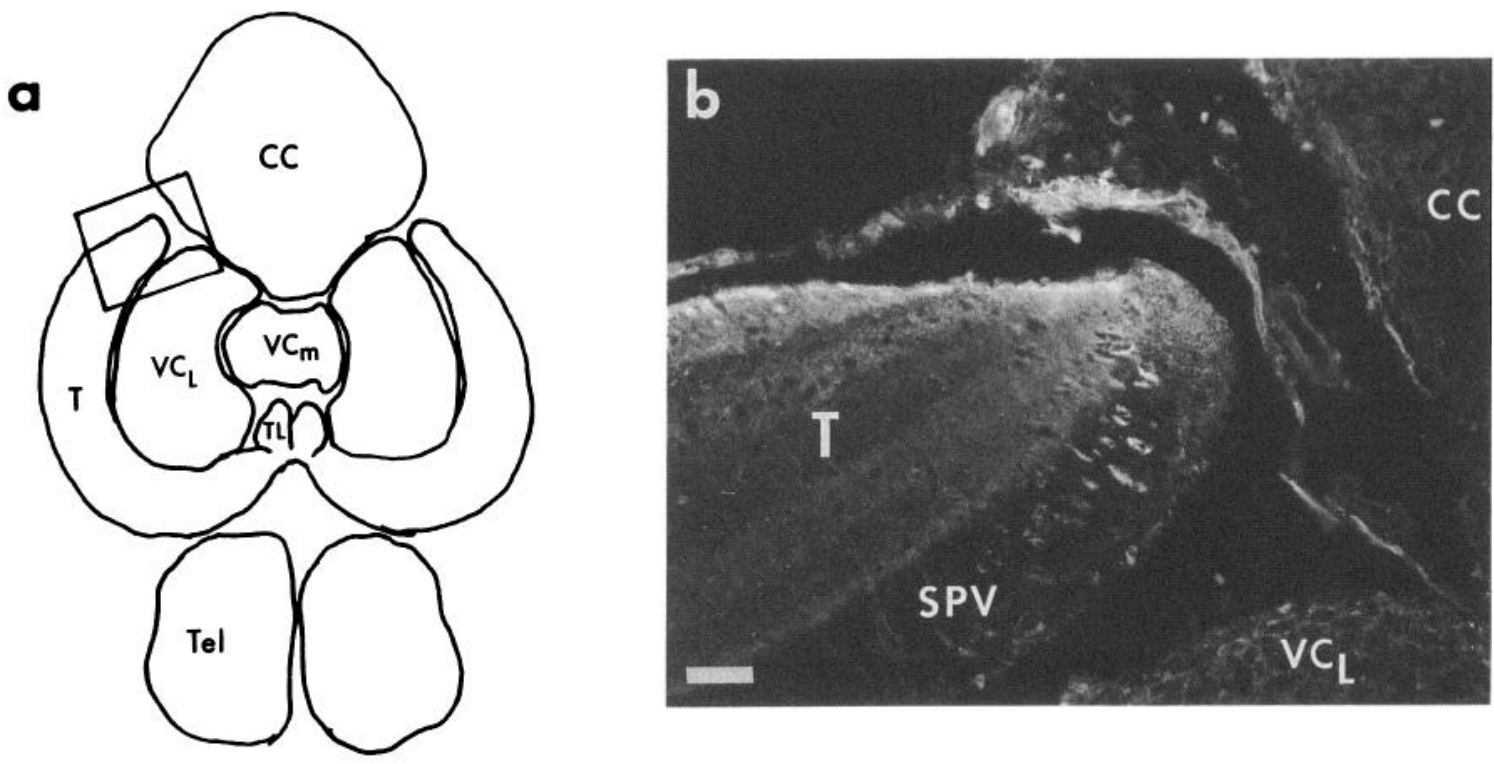

Figure 13. Horizontal section of control goldfish brain showing elevated anti-p68/70 immunofluorescence in the caudal tectum. The boxed region indicated in $a$ is shown at higher magnification in $b$. The elevation in immunofluorescence is particularly noticeable in the cell bodies within the SPV. Rostral structures are located at the bottom of the figure. $C C$, corpus cerebelli; $T$, optic tectum; $T e l$, telencephalon; $T L$, torus longitudinalis; $V C_{L}$, lateral lobe of the valvula cerebelli; $V C_{m}$, medial lobe of the valvula cerebelli. The immunoreactive material between the tectum and the corpus cerebelli is the pia-arachnoid, which separated from the surface of the brain. As in Figure 12, immunoreactive fibers can be seen within the SPV. Scale bar, $50 \mu \mathrm{m}$. 


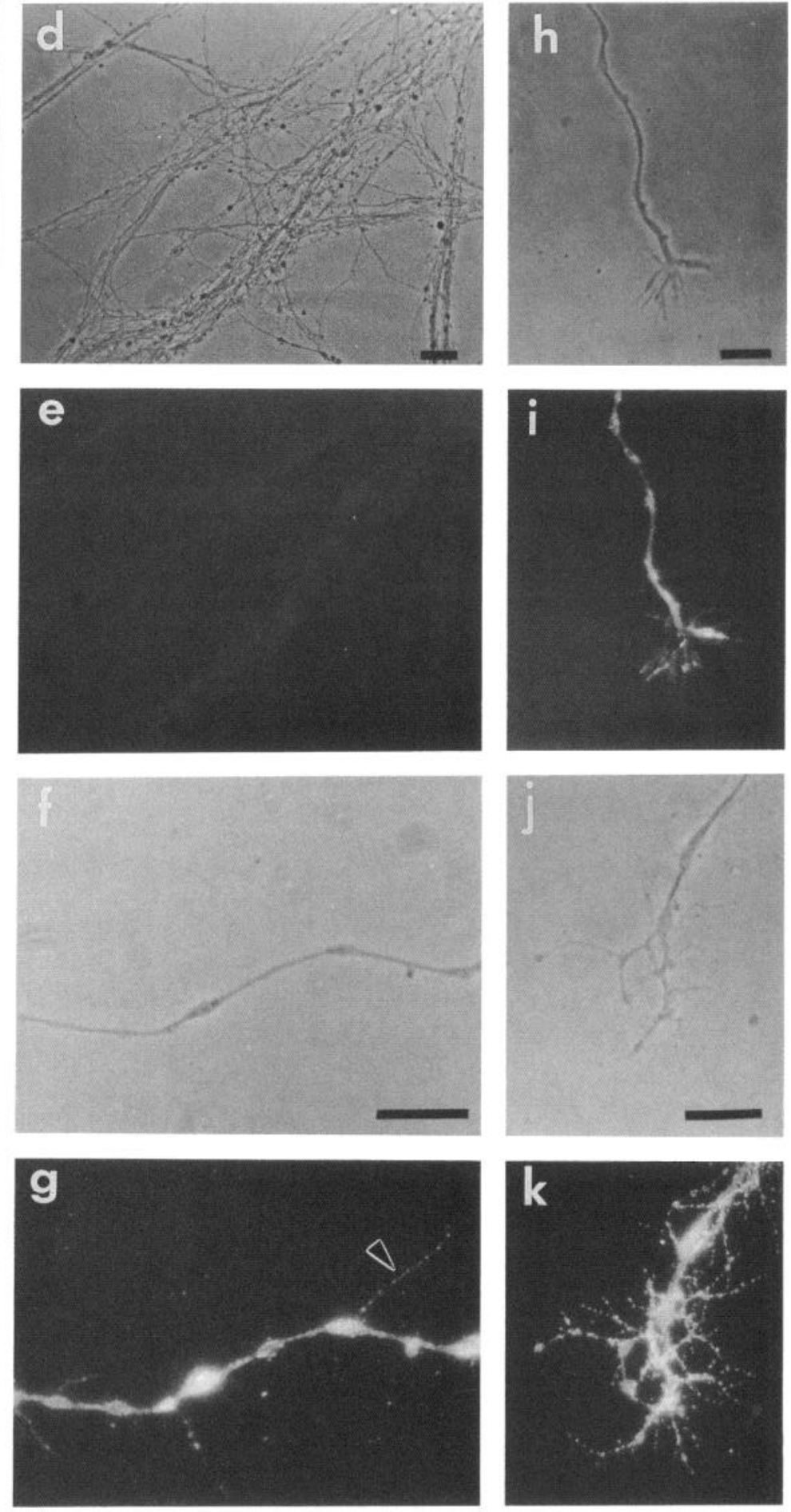

Figure 14. Immunofluorescence of neurites from goldfish retinal explants. $a-c$, Neurites seen by phase-contrast microscopy $(a)$ were labeled by anti-p68/70 (b) and anti-acetylated $\alpha$-tubulin ( $c$; ; bound antibodies were revealed by FITC- and TRITC-labeled secondary antibody, respectively. Anti-p68/70 immunofluorescence has a granular pattern, in contrast with the continuous filamentous pattern seen with anti-acetylated $\alpha$-tubulin. $d$ and $e$, Control study: phase-contrast image of neurites labeled with nonimmune $\operatorname{IgG}(d)$ and then incubated with FITC-labeled secondary antibody (e). No labeling is seen. $f$ and $g$, Phase-contrast micrograph of an individual neurite $(f)$ from an explant that had been processed for anti-p68/70 immunofluorescence, shown in $g$. Immunoreactivity is concentrated around membranous organelles and extends into filopodia-like extensions of the neurites (arrowhead). $h$, Distal segment and growth cone of what appears to be a single neurite, seen in phase contrast. $i$, Anti-p68/70 immunofluorescence shown in $h . j$, Phase-contrast micrograph of a growth cone at the tip of a compound neurite. $k$, Anti-p68/70 immunofluorescence of the growth cone shown in $j$. Anti-p68/70 labels the filopodia in a punctate pattern. Scale bars: $a-c, f-k, 10 \mu \mathrm{m} ; d$ and $e, 20 \mu \mathrm{m}$.

number (Raymond Johns and Easter, 1977). The addition of new neurons occurs primarily as an annulus at the periphery of the retina through the division and differentiation of cells in a circumferential germinal neuroepithelium (Raymond Johns,
1977; Meyer, 1978). Unlike other retinal neurons, rods are produced in adult goldfish by the division and differentiation of a population of precursor cells that are scattered throughout the retina in the ONL (Raymond Johns and Fernald, 1981). These 
rod precursors can be identified by their incorporation of intraocularly administered ${ }^{3} \mathrm{H}$-thymidine or $\mathrm{BrdU}$, and may give rise to other types of retinal cells after massive retinal damage (Raymond et al., 1988).

Neurogenesis also occurs in the optic tectum of adult goldfish. Unlike the symmetric addition of new neurons that occurs in the retina, cell addition in the tectum takes place exclusively at the caudal margin (Meyer, 1978; Raymond and Easter, 1983), resulting in a mismatch between new tectal neurons and the new optic fibers originating from the recently generated RGCs. The topographic organization of the retinotectal projection is nevertheless maintained by the continuous shifting of the RGC terminals (Cook et al., 1983; Easter and Stuermer, 1984; Raymond, 1986).

Characterization of anti-p68/70 immunoreactivity. In both immunoblots and tissue sections, differences in the observed anti-p68/70 immunoreactivity most likely reflect differences in p68/70 expression. This assertion is supported by the observation that changes in anti-p68/70 immunoreactivity correlate with the amount of $\mathrm{p} 68 / 70$ determined by independent means. For instance, in the immunoblot assay, the amount of immunoreactivity was linearly related to the amount of p68/70 standard applied to the gel (Fig. $3 a$ ). In addition, the increased antip68/70 immunoreactivity that was observed in PC optic nerve (Fig. 10) corresponds with a previously published account of increased p68/70 (as assessed by Coomassie blue-stained twodimensional gels) in regenerating optic nerve (Perry et al., 1985). The possibility cannot be ruled out that another process (c.g., posttranslational modification) affects the ability of the antibody to recognize $p 68 / 70$ and may be responsible for changes in antip68/70 immunoreactivity. Such a change would nevertheless reflect a difference in the biochemical state of p68/70 and consequently could be functionally significant.

Species distribution of anti-p68/70 immunoreactivity. The species distribution of anti-p68/70 cross-reactivity is limited to fish that are closely related to goldfish, and in general the intensity of the observed immunoreactive bands corresponds well to the presumed relationships of these fishes (see Nelson, 1984). However, although zebrafish (Brachydanio rerio) and goldfish (Carassius auratus) both belong to the minnow and carp family (Cyprinidae), the intensity of the cross-reactive band in zebrafish is much less than other fish of this family. In addition, fish of the sucker family (Catostomidae) and loach family (Cobitidae) exhibit more prominent bands than zebrafish. These differences might indicate that zebrafish express a $688 / 70$ homolog at lower levels than these other fish. Alternatively, the divergence of $\mathrm{p} 68$ / 70 epitopes between zebrafish and goldfish may be greater than that between goldfish and suckers or loaches. Likewise, the lack of immunoreactivity to anti-p68/70 in higher vertebrates may indicate either that higher vertebrates do not express a p68/70 homolog in brain, or alternatively that the epitopes recognized by anti-p68/70 have diverged significantly. This does not necessarily imply that the entire p68/70 molecule has diverged greatly between goldfish and mammals. It is possible that a large proportion of $\mathrm{p} 68 / 70$ is highly conserved between goldfish and mammals and is therefore nonimmunogenic when rabbits are used to produce an antibody against goldfish $\mathrm{p} 68 / 70$. The species specificity could reflect differences in a posttranslational modification, such as the nature of a carbohydrate substituent. In any case, given the limited species cross-reactivity of anti-p68/ 70 , identification of $\mathrm{p} 68 / 70$ homologs in higher vertebrates may require nonimmunological techniques.
Localization of anti-p68/70 immunoreactivity in the normal goldfish visual system. The present results using immunofluorescence provide direct confirmation of the synthesis of $p 68 / 70$ within RGCs. This localization had previously been indicated by the demonstrated axonal transport of p68/70 within the optic nerve (Heacock and Agranoff, 1982; Perry et al., 1985). The immunoreactivity of the IPL is likely to reflect the binding of anti-p68/70 to $\mathrm{RGC}$ dendrites, which ramify throughout this layer, since RGC ablation by application of propidium iodide to the optic nerve reduced IPL immunoreactivity (not shown). The anatomical basis for the elevated immunoreactivity within sublamina 3 is less clear. A number of subtypes of both ganglion and amacrine cells have processes that are distributed in this sublamina (Ramón y Cajal, 1972; Stell, 1985). In particular, processes of substance $\mathrm{P} /$ neurotensin-containing amacrine cells are very densely confined within sublamina 3 (Yazulla et al., 1985; Li et al., 1986). However, if the immunolabeling of amacrine cell processes accounted for the concentration of immunofluorescence in sublamina 3 , one also might expect to see immunofluorescence in the somata of amacrine cells since the cell bodies of other anti-p68/70+ cells were clearly labeled. Occasional cell bodies in the INL were labeled with anti-p68/70, but their size, morphology, and prevalence were more indicative of displaced ganglion cells than of amacrine cells. Thus, while the available information seems to indicate that the immunoreactivity of the IPL, including sublamina 3, represents the labeling of RGC dendrites, a contribution of other neuronal elements cannot be ruled out.

As a consequence of continued neurogenesis, adult goldfish RGCs exhibit both dendritic and axonal growth. Axonal extension of the RGCs to the tectum apparently occurs in recently born ganglion cells, since application of retrograde tracers to the optic nerve labels RGCs that lie immediately adjacent to the germinal zone (P. F. Hitchcock, personal communication). RGCs of the remaining retina are characterized by a more subtle form of axonal growth ("terminal shifting"), which occurs in order to maintain the topographic character of the retinotectal projection (Cook et al., 1983; Easter and Stuermer, 1984; Raymond, 1986). Like axons, dendrites of RGCs grow during adulthood, and this growth varies from peripheral to central retina (Hitchcock and Easter, 1986). By comparing the dendritic profiles of HRP-filled type 1.2 ganglion cells from small ( $\sim \mathrm{cm}$ long) and large ( $\sim 14 \mathrm{~cm}$ long) goldfish, Hitchcock and Easter (1986) calculated that the rate of increase in total dendritic length is higher in peripheral retina than in central retina. The capacity for regenerative growth also varies along the centroperipheral gradient, since neurite outgrowth is more extensive and occurs at a greater rate in explants from peripheral than central retina (Landreth and Agranoff, 1979). As shown in Figure 6, the intensity of anti-p68/70 immunofluorescence corresponds well with all of these manifestations of ganglion cell growth. Expression of p68/70 may therefore be an integral component of the biochemical program that leads to ganglion cell growth.

The presence of intense anti-p68/70 immunoreactivity both in the germinal neuroepithelium and in all layers of the retina immediately adjacent to it suggests that in addition to a role in dendritic and axonal growth, p68/70 may play a more general role in neuronal development. A similar pattern of immunoreactivity in the caudal tectum (Fig. 13), which like the peripheral retina is also a region of continuous neurogenesis (Meyer, 1978; Raymond and Easter, 1983), provides further support for this hypothesis. Cellular development in these germinal zones 
is of course a multifaceted process consisting of cell division, differentiation, axon/dendrite extension, synapse formation, and presumably many other subprocesses that are not as readily defined. From the present results, there is no way to determine which of these subprocesses might be associated with p68/70 expression, although the clear demonstration of p68/70 upregulation in RGCs during regeneration suggests that process elongation should be considered a primary candidate.

The link between p68/70 expression and cell growth and/or differentiation is strengthened by the finding that mitotically active rod precursor cells are labeled by anti-p68/70. The labeling of rod precursors was directly demonstrated in one experiment in which anti-p68/70 immunofluorescence was colocalized with the immunofluorescent detection of BrdU incorporation (Fig. 8). In addition, the relative abundance of anti-p68/70+, $\mathrm{NNI}^{-}$cells in the peripheral ONL (Fig. 7c) implies that these cells are rod precursors and/or recently born rods since dividing rod precursors are more commonly found in this region (Raymond Johns and Fernald, 1981). Given the large numbers of anti-p $68 / 70^{+}, \mathrm{NN}^{-}$cells in the peripheral ONL, and the fact that some of the anti-p68/70+ ONL cells had not incorporated BrdU, it is likely that the expression of antip68/70 immunoreactivity by rod precursors continues beyond cell division and is present in immature rods as well. The similarity in morphology between immature rods (Raymond and Rivlin, 1987) and anti-p68/70+, $\mathrm{NN1}{ }^{-}$cells also argues in support of this suggestion.

Expression of $p 68 / 70$ during regeneration and neurite outgrowth. A protein that displays increased synthesis during regeneration may play a functional role in the regeneration process. Increased amino acid incorporation may not necessarily indicate an elevated amount of protein, but instead might reflect increased turnover without an actual change in the amount of the protein supplied to the growing neuron. Until the present experiments, it was not clear that the amount of p68/70 increased during regeneration, since the enhanced incorporation of radiolabeled amino acids into p68/70 following optic nerve crush (Heacock and Agranoff, 1982; Agranoff and Ford-Holevinski, 1984; Perry et al., 1985; Perrone-Bizzozero and Benowitz, 1987) had not been shown to be accompanied by elevated p68/70 levels in the retina. As noted above, Perry et al. (1985) observed an increased amount of Coomassic bluc-staincd p68/70 within two-dimensional gels of 3 week PC optic nerve homogenates, but whether this increase occurred in regenerating axons or in cells intrinsic to the optic nerve was not determined. The latter possibility could not be discounted since these cells were also shown to synthesize p68/70 (Perry et al., 1985).

The present experiments indicate that the amount of p68/70 is indeed increased within regenerating neurons (Fig. 9). In retinal homogenates, the increase in anti-p68/70 immunoreactivity was greatest (approximately threefold) at $48 \mathrm{~d}$ PC. Estimating that $75 \%$ of the retinal anti-p $68 / 70$ immunoreactivity occurs within ganglion cells and their processes, the increase in immunoreactivity within the ganglion cells would actually be fourfold, assuming that there were no changes in anti-p68/70 immunoreactivity associated with cells other than the RGCs. Since immunofluorescent analysis of $\mathrm{C}$ and $\mathrm{PC}$ retinas from $14 \mathrm{~d} \mathrm{PC}$ fish revealed that increased anti-p68/70 immunoreactivity occurred primarily in the cell bodies and processes of the regenerating RGCs (Fig. 9b,c), this assumption appears to be essentially correct.

The cause for the hypertrophy and elevated anti-p68/70 im- munoreactivity of the ganglion cells such as that shown in Figure 10 is not known. The most parsimonious explanation is that this fish had a small, preexisting lesion of the optic nerve that damaged relatively few $\mathrm{RGC}$ axons. If this were the case, all of the damaged RGCs would be expected to occur in a similar centroperipheral position, given the arrangement of RGC axons within the optic nerve (Rusoff and Easter, 1980). The location of both of the observed cells is consistent with this prediction. Regardless of the explanation for the presence of these cells in normal retina, the fact that they are not surrounded by cells with similar levels of immunoreactivity implies that the mechanism leading to elevated $\mathrm{p} 68 / 70$ expression can be localized within single cells and is not a disseminated tissue response. Diffuse responses to axonal injury have previously been noted for ornithine decarboxylase (Kohsaka et al., 1981), acid phosphatase (Kaye and Austin, 1975), succinate dehydrogenase (Hamberger and Sjöstrand, 1966), and carbamoyl phosphate synthetase (Kaye and Austin, 1975).

In addition to the retina, anti-p68/70 immunoreactivity in creases in the optic nerve and in the retinorecipient layers of the tectum following RGC axotomy. Since the non-neuronal elements of both $\mathrm{C}$ and PC optic nerve are strongly immunoreactive, the specific increase of anti-p68/70 immunoreactivity in RGC axons will be much higher than the maximal twofold increase in anti-p68/70 immunoreactivity seen in optic nerve homogenates. The same situation occurs in tectum, where the increase in immunofluorescence of RGC axons within the tectum is dramatic, even though the change in homogenates of whole tectum is modest. The increase in immunofluorescence of the PC optic nerve and tectum (Figs. 11, 12) might represent in part the addition of new fibers, since quantitative morphometric methods have shown that following optic nerve crush the number of RGC axons increases distal to the crush site (Murray, 1982; Murray and Edwards, 1982).

The presence of high levels of anti-p68/70 immunoreactivity in regenerating $\mathrm{RGC}$ neurites in retinal explant cultures (Fig. 14) is consistent with the increased RGC axonal immunolabeling seen in tissue sections. In addition, immunoreactivity in neurites in culture was localized to structures that may play a role in axonal elongation: growth cones, filopodia, and membranous organelles, which supply membrane to the growing neurite tip. At first glance, the association of anti-p68/70 with the membranous organelles might not seem to be consistent with the slow transport of $\mathrm{p} 68 / 70$, since membranous organelles are conveyed via fast transport. If p68/70 is in equilibrium between soluble and membrane-bound states, however, the slow transport of a pool of $\mathrm{p} 68 / 70$ would still be possible. Consistent with this hypothesis, p68/70 is found both in high-speed supernatant fractions and in membrane pellet fractions (M. L. Leski, personal communication). Spectrin, actin, and calmodulin have been localized with immunofluorescence to membranous organelles in goldfish RGC neurites (Koenig et al., 1985), yet actin and calmodulin are axonally transported by slow transport (Black and Lasek, 1980; Brady et al., 1981). Like p68/70, actin is also a primary constituent of growth cones and filopodia in goldfish neurites (Koenig et al., 1985), so an association between actin and p68/70 may exist. It is clear from immunofluorescence experiments (Fig. 14) that the distribution of p68/70 differs sharply from that of the filamentous protein tubulin.

Significance of p68/70 expression. The present studies are consistent with previous indications of $\mathrm{p} 68 / 70$ involvement in the outgrowth of neuronal processes (Heacock and Agranoff, 
1982). While the doublet is a marker of neuronal growth and process extension, it differs from such proteins as GAP-43 (Willard et al., 1984) in that it is not limited to the nervous system and is present in brain constitutively in substantial amounts, increasing one- or twofold in regenerating tissue. In contrast, its radiolabeling may be increased in regenerating tissue by one or two magnitudes.

The expression of p68/70 during neuronal development (i.e., in the germinal zones and rod precursors) and axonal/neuritic outgrowth (in regenerating and explanted ganglion cells) suggests that p68/70 is expressed by cells as part of a biochemically defined growth state. In an analogous manner, the developmentally regulated neural cell adhesion molecule (N-CAM) has also been localized to developing and regenerating axons and the growing margins of the goldfish retina and tectum (Bastmeyer et al., 1990). While the similar distribution of $\mathrm{p} 68 / 70$ and N-CAM in these areas does not necessarily imply that p68/ 70 is involved in cellular adhesion, it does suggest that $\mathrm{p} 68 / 70$ may be expressed as part of a developmental sequence that also leads to N-CAM expression.

Increased expression of p68/70 has been observed in every instance of developing and regenerating goldfish neurons thus far examined. In addition, p68/70 is expressed in non-neuronal cells that are not undergoing an obvious developmental change: in microglia within the retina (see Fig. 7), in scleral connective tissue cells (see Fig. 5), and in optic nerve glia (see Fig. 10). The presence of $\mathrm{p} 68 / 70$ in these cells suggests that the doublet plays additional cellular roles, perhaps reflecting a more fundamental cellular capacity to undergo developmental change.

\section{References}

Agranoff BW, Ford-Holevinski TS (1984) Biochemical aspects of the regenerating goldfish visual system. In: Advances in Neurochemistry, Vol 6. Axonal transport in neuronal growth and regeneration (Elam JS, Cancalon P, eds), pp 69-86. New York: Plenum.

Attardi DG, Sperry RW (1963) Preferential selection of central pathways by regenerating optic fibers. Exp Neurol 7:46-64

Barthel LK, Raymond PA (1990) Improved method for obtaining 3- $\mu \mathrm{m}$ cryosections for immunocytochemistry. J Histochem Cytochem 38:1383-1388.

Bastmeyer M, Schlosshauer B, Stuermer CAO (1990) The spatiotemporal distribution of N-CAM in the retinotectal pathway of adult goldfish detected by the monoclonal antibody D3. Development 108: 299-311.

Black MM, Lasek RJ (1980) Slow components of axonal transport: two cytoskeletal networks. J Cell Biol 86:616-623.

Brady ST, Tytell M, Heriot K, Lasek RJ (1981) Axonal transport of calmodulin: a physiologic approach to identification of long-term associations between proteins. J Cell Biol 89:607-614.

Burrell HR, Dokas LA, Agranoff BW (1978) RNA metabolism in the goldfish retina during optic nerve regeneration. J Neurochem 31: 289-298.

Burrell HR, Heacock AM, Water RD, Agranoff BW (1979) Increased tubulin messenger RNA in the goldfish retina during optic nerve regeneration. Brain Res 168:628-632.

Cook JE, Rankin ECC, Stevens HP (1983) A pattern of optic axons in the normal goldfish tectum consistent with the caudal migration of optic terminals during development. Exp Brain Res 52:147-151.

Dokas LA, Kohsaka S, Burrell HR, Agranoff BW (1981) Uridine metabolism in the goldfish retina during optic nerve regeneration: whole retina studies. J Neurochem 36:1 160-1165.

Easter SS Jr, Stuermer CAO (1984) An evaluation of the hypothesis of shifting terminals in goldfish optic tectum. J Neurosci 4:1052-1063.

Giulian D, Des Ruisseaux H, Cowbur D (1980) Biosynthesis and intraaxonal transport of proteins during neuronal regeneration. J Biol Chem 255:6494-6501.

Hamberger A, Sjöstrand J (1966) Respiratory enzyme activities in neurons and glial cells of the hypoglossal nucleus during nerve regeneration. Acta Physiol Scand 67:76-88.

Heacock AM, Agranoff BW (1976) Enhanced labeling of a retinal protein during regeneration of optic nerve in goldfish. Proc Natl Acad Sci USA 73:828-832.

Heacock AM, Agranoff BW (1982) Protein synthesis and transport in the regenerating goldfish visual system. Neurochem Res 7:771-788.

Hitchcock PF, Easter SS Jr (1986) Retinal ganglion cells in goldfish: a qualitative classification into cell types, and a quantitative study of the development of one of them. J Neurosci 6:1037-1050.

Kaye P, Austin L (1975) Neural metabolic responses to axon damage. Proc Aust Biochem Soc 8:118.

Knight JK, Raymond PA (1990) Time course of opsin expression in developing rod photoreceptors. Development 110:1115-1120.

Koenig E, Kinsman S, Repasky E, Sultz L (1985) Rapid mobility of motile varicosities and inclusions containing $\alpha$-spectrin, actin, and calmodulin in regenerating axons in vitro. J Neurosci 5:715-729.

Kohsaka S, Dokas LA, Agranoff BW (1981) Metabolism in the goldfish retina during optic nerve regeneration: cell-free preparations. J Neurochem 36:1166-1174.

Kurecki T, Kress LF, Laskowski M (1979) Purification of human plasma $\alpha_{2}$ macroglobulin and $\alpha_{1}$ proteinase inhibitor using zinc chelate chromatography. Anal Biochem 99:415-420.

Laemmli UK (1970) Cleavage of structural proteins during the assembly of the head of bacteriophage T4. Nature 227:680-685.

Landreth GE, Agranoff BW (1979) Explant culture of adult goldfish retina: a model for the study of CNS regeneration. Brain Res 161: 39-53.

Lee C, Levin A, Branton D (1987) Copper staining: a five-minute protein stain for sodium dodecyl sulfate-polyacrylamide gels. Anal Biochem 166:308-312.

Li H-B, Marshak DW, Dowling JE, Lam DM-K (1986) Colocalization of immunoreactive substance $P$ and neurotensin in amacrine cells of the goldfish retina. Brain Res 366:307-313.

Meyer RL (1978) Evidence from thymidine labeling for continuing growth of retina and tectum in juvenile goldfish. Exp Neurol 59: 99-111.

Murray M (1982) A quantitative study of regenerative sprouting by optic axons in goldfish. J Comp Neurol 209:352-362.

Murray M, Edwards MA (1982) A quantitative study of the reinnervation of the goldfish optic tectum following optic nerve crush. J Comp Neurol 209:363-373.

Murray M, Grafstein B (1969) Changes in the morphology and amino acid incorporation of regenerating goldfish optic neurons. Exp Neurol 23:544-560.

Nelson JS (1984) Fishes of the world, 2d ed. New York: Wiley.

Olmsted JB (1981) Affinity purification of antibodies from diazotized paper blots of heterogeneous protein samples. J Biol Chem 256: 11955-11957.

Perrone-Bizzozero NI, Benowitz LI (1987) Expression of a 48-kilodalton growth-associated protein in the goldfish retina. J Neurochem 48:644-652.

Perry GW, Burmeister DW, Grafstein B (1985) Changes in protein content of goldfish optic nerve during degeneration and regeneration following nerve crush. J Neurochem 44:1142-1151.

Piperno G, Fuller MT (1985) Monoclonal antibodies specific for an acetylated form of $\alpha$-tubulin recognize antigens in cilia and flagella from a variety of organisms. J Cell Biol 101:2085-2094.

Ramón y Cajal S (1972) The structure of the retina (compiled and translated by SA Thorpe and M Glickstein). Springfield, IL: Thomas.

Raymond PA (1986) Movement of retinal terminals in goldfish optic tectum predicted by analysis of neuronal proliferation. J Neurosci 6:2479-2488.

Raymond PA, Easter SS Jr (1983) Postembryonic growth of the optic tectum in goldfish. I. Location of germinal cells and numbers of neurons produced. J Neurosci 3:1077-1091.

Raymond PA, Rivlin PK (1987) Germinal cells in the goldfish that produce rod photoreceptors. Dev Biol 122:120-138.

Raymond PA, Reiffler M, Rivlin PK (1988) Regeneration of goldfish retina: rod precursors are a likely source of regenerating cells. J Neurobiol 19:431-463.

Raymond Johns PA (1977) Growth of the adult goldfish eye. III. Source of the new retinal cells. J Comp Neurol 176:343-358.

Raymond Johns PA, Easter SS Jr (1977) Growth of the adult goldfish eye. II. Increase in retinal cell number. J Comp Neurol 176:331-342. 
Raymond Johns PA, Fernald RD (1981) Genesis of rods in teleost fish retina. Nature 29:141-142.

Rusoff AC, Easter SS Jr (1980) Order in the optic nerve of goldfish. Science 208:311-312.

Skene JHP, Willard M (1981a) Changes in axonally transported proteins during axon regeneration in toad retinal ganglion cells. $J$ Cell Biol 89:86-95.

Skene JHP, Willard M (1981b) Axonally transported proteins associated with axon growth in rabbit central and peripheral nervous system. J Cell Biol 89:96-103.

Smith PK, Krohn RI, Hermanson GT, Mallia AK, Gartner FH, Provenzano MD, Fujimoto EK, Goeke NM, Olson BJ, Klenk DC (1985) Measurement of protein using bicinchoninic acid. Anal Biochem 150: 76-85.

Springer AD, Agranoff BW (1977) Effect of temperature on rate of goldfish optic nerve regeneration: a radioautographic and behavioral study. Brain Res 128:405-415.
Stell WK (1985) Putative peptide transmitters, amacrine cell diversity and function in the inner plexiform layer. In: Neurocircuitry of the retina, a Cajal memorial (Galledo A, Gouras P, eds), pp 171-187. New York: Elsevier.

Wagner EC, Raymond PA (1991) Müller glial cells of the goldfish retina are phagocytic in vitro but not in vivo. Exp Eye Res 53:583-589.

Willard M, Skene JHP, Simon C, Meiri K, Hirokawa N, Glicksman $\mathrm{Mfb}(1984)$ Regulation of axon growth and cytoskeletal development. In: Advances in neurochemistry, $\mathrm{Vol} 6$, Axonal transport in neuronal growth and regeneration (Elam JS, Cancalon P, eds), pp 171-183. New York: Plenum.

Wilmot GR, Ford-Holevinski TH, Agranoff BW (1987) Further characterization of a regeneration-specific cytosolic protein in the goldfish visual system. Soc Neurosci Abstr 13:972.

Yazulla S, Studholme KM, Zucker CL (1985) Synaptic organization of substance P-like immunoreactive amacrine cells in goldfish retina. J Comp Neurol 231:232-238. 